\title{
Age of the Mt. Ortles ice cores, the Tyrolean Iceman and glaciation of the highest summit of South Tyrol since the Northern Hemisphere Climatic Optimum
}

\author{
Paolo Gabrielli ${ }^{1,2}$, Carlo Barbante ${ }^{3,4,5}$, Giuliano Bertagna ${ }^{1}$, Michele Bertó ${ }^{3}$, Daniel Binder ${ }^{6}$, Alberto Carton $^{7}$, \\ Luca Carturan $^{8}$, Federico Cazorzi ${ }^{9}$, Giulio Cozzi ${ }^{3,4}$, Giancarlo Dalla Fontana ${ }^{8}$, Mary Davis ${ }^{1}$, Fabrizio De Blasi ${ }^{8}$, \\ Roberto Dinale $^{10}$, Gianfranco Dragà ${ }^{11}$, Giuliano Dreossi ${ }^{3}$, Daniela Festi ${ }^{12}$, Massimo Frezzotti ${ }^{13}$, Jacopo Gabrieli ${ }^{3,4}$, \\ Stephan P. Galos ${ }^{14}$, Patrick Ginot ${ }^{15,16}$, Petra Heidenwolf ${ }^{12}$, Theo M. Jenk ${ }^{17}$, Natalie Kehrwald ${ }^{18}$, Donald Kenny ${ }^{1}$, \\ Olivier Magand ${ }^{15,16}$, Volkmar Mair ${ }^{19}$, Vladimir Mikhalenko ${ }^{20}$, Ping Nan Lin ${ }^{1}$, Klaus Oeggl ${ }^{12}$, Gianni Piffer $^{21}$, \\ Mirko Rinaldi $^{21}$, Ulrich Schotterer ${ }^{22}$, Margit Schwikowski ${ }^{17}$, Roberto Seppi ${ }^{23}$, Andrea Spolaor ${ }^{3}$, Barbara Stenni ${ }^{3}$, \\ David Tonidandel ${ }^{19}$, Chiara Uglietti ${ }^{17}$, Victor Zagorodnov ${ }^{1}$, Thomas Zanoner ${ }^{7}$, and Piero Zennaro ${ }^{3}$ \\ ${ }^{1}$ Byrd Polar and Climate Research Center, The Ohio State University, Columbus, 43210, USA \\ ${ }^{2}$ School of Earth Sciences, The Ohio State University, 275 Mendenhall Laboratory, Columbus, 43210, USA \\ ${ }^{3}$ Department of Environmental Sciences, Informatics and Statistics, Ca' Foscari University of Venice, \\ 30170 Venice-Mestre, Italy \\ ${ }^{4}$ Istituto per la Dinamica dei Processi Ambientali-CNR, 30170 Venice-Mestre, Italy \\ ${ }^{5}$ Accademia Nazionale dei Lincei, 00196 Rome, Italy \\ ${ }^{6}$ Climate Research Section, Central Institute for Meteorology and Geodynamics ZAMG, 1190 Vienna, Austria \\ ${ }^{7}$ Department of Geosciences, University of Padova, 35131 Padova, Italy \\ ${ }^{8}$ Department of Land, Environment, Agriculture and Forestry, University of Padova, Agripolis, 35020 Legnaro, Italy \\ ${ }^{9}$ Dipartimento di Scienze Agro-Alimentari, Ambientali e Animali, Università di Udine, 33100 Udine, Italy \\ ${ }^{10}$ Ufficio Idrografico, Provincia Autonoma di Bolzano, 39100 Bolzano, Italy \\ ${ }^{11}$ Geologin, 39040 Varna, Italy \\ ${ }^{12}$ Institute for Botany, University of Innsbruck, 6020 Innsbruck, Austria \\ ${ }^{13}$ ENEA, 00196 Rome, Italy \\ ${ }^{14}$ Institute of Atmospheric and Cryospheric Sciences, University of Innsbruck, 6020 Innsbruck, Austria \\ ${ }^{15}$ Laboratoire de Glaciologie et Géophysique de l'Environnement (LGGE), CNRS, 38041 Grenoble, France \\ ${ }^{16}$ University Grenoble Alpes, 38041 Grenoble, France \\ ${ }^{17}$ Laboratory of Environmental Chemistry, Paul Scherrer Institut, 5232 Villigen, Switzerland \\ ${ }^{18}$ Geosciences and Environmental Change Science Center, U.S. Geological Survey, Denver, 80225, USA \\ ${ }^{19}$ Ufficio Geologia e Prove materiali, Provincia Autonoma di Bolzano, 39053 Kardano, Italy \\ ${ }^{20}$ Institute of Geography, Russian Academy of Sciences, 119017 Moscow, Russia \\ ${ }^{21}$ Waterstones Geomonitoring, 39044 Egna, Italy \\ ${ }^{22}$ University of Bern, 3012 Bern, Switzerland \\ ${ }^{23}$ Department of Earth and Environmental Sciences, University of Pavia, 27100 Pavia, Italy
}

Correspondence to: Paolo Gabrielli (gabrielli.1@ osu.edu)

Received: 30 June 2016 - Published in The Cryosphere Discuss.: 12 July 2016

Revised: 17 October 2016 - Accepted: 18 October 2016 - Published: 17 November 2016

Published by Copernicus Publications on behalf of the European Geosciences Union. 
Abstract. In 2011 four ice cores were extracted from the summit of Alto dell'Ortles ( $3859 \mathrm{~m}$ ), the highest glacier of South Tyrol in the Italian Alps. This drilling site is located only $37 \mathrm{~km}$ southwest from where the Tyrolean Iceman, $\sim 5.3 \mathrm{kyrs}$ old, was discovered emerging from the ablating ice field of Tisenjoch $(3210 \mathrm{~m}$, near the Italian-Austrian border) in 1991. The excellent preservation of this mummy suggested that the Tyrolean Iceman was continuously embedded in prehistoric ice and that additional ancient ice was likely preserved elsewhere in South Tyrol. Dating of the ice cores from Alto dell'Ortles based on ${ }^{210} \mathrm{~Pb}$, tritium, beta activity and ${ }^{14} \mathrm{C}$ determinations, combined with an empirical model (COPRA), provides evidence for a chronologically ordered ice stratigraphy from the modern glacier surface down to the bottom ice layers with an age of $\sim 7 \mathrm{kyrs}$, which confirms the hypothesis. Our results indicate that the drilling site has continuously been glaciated on frozen bedrock since $\sim 7$ kyrs BP. Absence of older ice on the highest glacier of South Tyrol is consistent with the removal of basal ice from bedrock during the Northern Hemisphere Climatic Optimum (6-9 kyrs BP), the warmest interval in the European Alps during the Holocene. Borehole inclinometric measurements of the current glacier flow combined with surface ground penetration radar (GPR) measurements indicate that, due to the sustained atmospheric warming since the 1980s, an acceleration of the glacier Alto dell'Ortles flow has just recently begun. Given the stratigraphic-chronological continuity of the Mt. Ortles cores over millennia, it can be argued that this behaviour has been unprecedented at this location since the Northern Hemisphere Climatic Optimum.

\section{Introduction}

Glaciers are sensitive indicators of climate change as their length, area and volume respond primarily to variations in air temperature and precipitation (e.g. Oerlemans, 2001). In general small and steep alpine glaciers show faster response $(\sim 10$ years) to climate fluctuations than large, less inclined ice bodies ( $\sim 100$ years) (Holzhauser, 1997). In the European Alps, glaciers have undergone major variations at glacialinterglacial timescales as they greatly expanded during the last glacial period and contracted dramatically during the last deglaciation (Ivy-Ochs et al., 2008). While traces of the large expansions of the last glacial period are well preserved even at very low elevations (Ravazzi et al., 2014), evidence for the subsequent smaller Holocene glacier variations is most often overridden by the Little Ice Age expansion (LIA; 14th-19th century). Nevertheless organic fragments (e.g. wood, peat bogs) found recently in forefields of retreating glaciers provide information on the lower altitude limits of past glacial extents, demonstrating that glaciers in the Alps were smaller during the mid-Holocene than they are today (Hormes et al.,
2001; Joerin et al., 2006, 2008; Nicolussi and Patzelt, 2000; Porter and Orombelli, 1985).

The end of the Younger Dryas $(11.7 \mathrm{kyrs} \mathrm{BP})$ is generally considered to mark the onset of the Holocene. At that time conditions favourable to glaciers persisted in the European Alps until 10.5 kyrs BP (Ivy-Ochs et al., 2009) when a period of climatic warming started, culminating between 6 and 9 kyrs BP during the so-called Northern Hemisphere Climatic Optimum (Vollweiler et al., 2006). At this time the Northern Hemisphere summer insolation and solar irradiance reached maximum levels during the Holocene (Berger and Loutre, 1991; Stuiver et al., 1998). Specifically, this climatic optimum was characterized by three particularly warm phases at 9.2, 7.45-6.65 and 6.20-5.65 kyrs BP (Joerin et al., 2008). A climate that was generally unfavourable for glacier advances persisted at least until $6.8 \mathrm{kyrs}$ BP (Luetscher et al., 2011). Between 5.3 and 3.3 kyrs BP the changed climatic conditions marked the beginning of the Neoglaciation in the European Alps (Magny and Haas, 2004; Ivy-Ochs et al., 2009). During this new phase glaciers showed larger variations which culminated in three large LIA expansions (14th, 17th and 19th centuries) (Holzhauser et al., 2005), followed by an ongoing phase of intense glacier waning (Zemp et al., 2006).

At the end of summer 1991, the 5300-year-old Tyrolean Iceman mummy emerged from the ablating ice field of the Tisenjoch, a saddle at $3210 \mathrm{~m}$ near the Italian-Austrian border in the eastern Alps (Seidler et al., 1992). The excellent state of preservation of the Tyrolean Iceman provides strong evidence for the minimum coverage of this ice field at this time, which has only recently been surpassed. This discovery suggests that past atmospheric temperatures characterizing warm phases such as the Roman (250 BC-400 AD) and the Medieval (950-1250 AD) periods may have never exceeded that of the current time in this sector of the Alps (Baroni and Orombelli, 1996). However, a recent chironomid-based summer air temperature reconstruction from Lake Silvaplana, in the nearby Upper Engadine (Switzerland), documented that the 20th century and the Medieval period (from $1030 \mathrm{AD}$, start of the dataset, until $1260 \mathrm{AD}$ ) were both $1^{\circ} \mathrm{C}$ warmer than the modern climate reference period (1961-1990) in the eastern Alps (Larocque-Tobler et al., 2010). Clearly, information about the glaciation of the eastern Alps before the LIA remains sparse (Nicolussi and Patzelt, 2000).

In this context ice cores can provide useful information. In the western Alps, an ice core extracted from Colle Gnifetti (4450 m, Monte Rosa, Italian-Swiss border) provided evidence for more than $\sim 10 \mathrm{kyr}$-old ice in its lower section (Jenk et al., 2009), suggesting a continuous glaciation of at least the highest locations of the western Alps throughout the Holocene. In 1991, at the time of the discovery of the Tyrolean Iceman, only pollen analyses (Bortenschlager et al., 1992) were performed on the ice in which this mummy was embedded for $\sim 5.3 \mathrm{kyrs}$ at the Tisenjoch, which is now completely deglaciated. This is unfortunate because this now 
melted ice had the potential to be as old as the Tyrolean Iceman himself, and may have preserved a unique snapshot of additional information of the past environmental conditions experienced by the Alpine populations during the midHolocene.

In 2010, we formulated the hypothesis that an ice core record encompassing the time of the Tyrolean Iceman was embedded in the upper reaches of the Alto dell'Ortles $(3859 \mathrm{~m})$, the main glacier of Mt. Ortles (3905 m, Italy), which is the highest mountain of South Tyrol, located $37 \mathrm{~km}$ from the Tisenjoch (Gabrielli et al., 2010). This idea was based on the following observations: (i) Alto dell'Ortles is wind-exposed and located in a rain shadow (Schwarb, 2000), and thus is likely characterized by a low accumulation rate compared to the average of the Alps; (ii) the upper exposed margins of Alto dell'Ortles show laminated ice layers down to bedrock; and (iii) the concomitant significant thickness and moderate tilt $\left(8-9^{\circ}\right)$ of the upper part of Alto dell'Ortles may be indicative of minimal basal flow and a frozen ice/bedrock interface, as it could have also been expected at this elevation in this area (Suter et al., 2001).

Until recently, alpine ice core records have been obtained only from the western Alps (Barbante et al., 2001, 2004; Jenk et al., 2009; Legrand et al., 2003; Preunkert et al., 2000, 2001; Schwikowski et al., 1999a, b; Van de Velde et al., 2000a; Wagenbach et al., 1988) because of their high elevation and the consequent common occurrence of the cold firn zone (Golubev, 1975; Haeberli and Alean, 1985), which is more likely to retain climatic and environmental signals (Eichler et al., 2001). In contrast, because of their lower elevation, the highest glaciers in the eastern Alps were assumed to be entirely within the temperate firn zone, and thus unsuitable for preserving intact ice core records (Oerter et al., 1985). However, Suter and co-workers modelled the firn temperature in the Alps and, based on altitude and exposure, suggested that cold firn should exist above $3400 \mathrm{~m}$ in northerly aspects and above $4150 \mathrm{~m}$ on southern slopes (Suter et al., 2001).

Modern climatic conditions in the eastern Alps are very unusual because since $\sim 1980$ summer air temperatures have shown a step increase of about $2{ }^{\circ} \mathrm{C}$ at high elevations (Gabrielli et al., 2010; Auer et al., 2006). Consequently the extensive summer meltwater percolation through the shallow $(<10 \mathrm{~m})$ temperate firn layers, recently observed on Mt. Ortles, could be a relatively recent phenomenon that intensified after $\sim 1980$ (Gabrielli et al., 2010). Interestingly, ice that preserved climatic and environmental signals was already found in 2003 below temperate firn on the Quelccaya ice cap in the Peruvian Andes, where recent and strong meltwater percolation did not affect the climatic signal embedded within the deepest impermeable ice layers (Thompson et al., 2006). We likewise speculated that a climatic signal might still be preserved within the deep ice layers of the glacier Alto dell'Ortles (Gabrielli et al., 2010).
During the autumn of 2011, working within the framework of an international program aimed at studying past and present climate conditions in the Alps ("Ortles Project", www.ortles.org), we extracted the first ice cores drilled to bedrock in the eastern Alps from Alto dell'Ortles (Gabrielli et al., 2012). Here we present glaciological observations (a digital elevation model, englacial characteristics, glacial dynamic and bedrock topography of the drilling site) and various dating techniques (based on tritium, beta emissions, ${ }^{137} \mathrm{Cs},{ }^{210} \mathrm{~Pb}$ and ${ }^{14} \mathrm{C}$ ) that allowed a timescale for the Mt. Ortles ice cores to be obtained. We show that the Alto dell'Ortles cores contain records at millennial timescales, and that the bottom ice dates back $\sim 7 \mathrm{kyrs}$ BP. Combining ice core and glaciological observations, we discuss these findings in light of the state of the knowledge of the glaciation of the eastern Alps during the Holocene.

\section{The drilling site}

\subsection{General characteristics}

The Alto dell'Ortles glacier covers the northwestern side of Mt. Ortles, which gently slopes $\left(8-9^{\circ}\right)$ from near the summit for $\sim 300 \mathrm{~m}$, then flows on steeper bedrock into two major tongues down to $3018 \mathrm{~m}$ (Fig. 1). According to some recent lidar measurements (see Sect. 2.2.2), the total surface area was $1.12 \mathrm{~km}^{2}$ in 2011 and $1.07 \mathrm{~km}^{2}$ in 2013 , of which $\sim 10 \%$ constitutes the upper gentle plateau. The ice core drilling campaign was conducted during September and October 2011 on a small col $\left(3859 \mathrm{~m} ; 10^{\circ} 32^{\prime \prime} 34,46^{\circ} 30^{\prime \prime} 25\right)$ between the summit of Mt. Ortles (3905 m) and the Vorgipfel (3845 m) (Figs. 1-2). At the drilling site, the bedrock is at $\sim 75 \mathrm{~m}$ of depth (Gabrielli et al., 2010, 2012) and the current accumulation rate (2011-2013) is $\sim 800 \mathrm{~mm}$ water equivalent (w.e.) per year.

Over the last 3 decades (1980-2009) the reconstructed average summer (JJA) air temperature was $-1.6{ }^{\circ} \mathrm{C}, \sim 2{ }^{\circ} \mathrm{C}$ higher than during the previous 115 years, with a peak of $+2{ }^{\circ} \mathrm{C}$ during the summer of 2003 (Gabrielli et al., 2010). In 2011 , englacial temperatures provided firm evidence for the concomitant presence of a temperate firn portion, deep cold ice layers and a frozen bedrock. In fact, thermistors located within the firn indicated temperatures at or near the pressure melting point, while those positioned in the ice (below the firn ice transition at $\sim 30 \mathrm{~m}$ depth) clearly demonstrate negative temperatures at $35 \mathrm{~m}\left(-0.4^{\circ} \mathrm{C}\right), 55 \mathrm{~m}\left(-1.8^{\circ} \mathrm{C}\right)$ and at $75 \mathrm{~m}\left(-2.8^{\circ} \mathrm{C}\right)$ close to bedrock, confirming the presence of cold ice (Gabrielli et al., 2012). We concluded that this glacier probably represents a unique remnant of the colder climate prior to $\sim 1980$, which has since been shifting from a cold to a temperate state. 


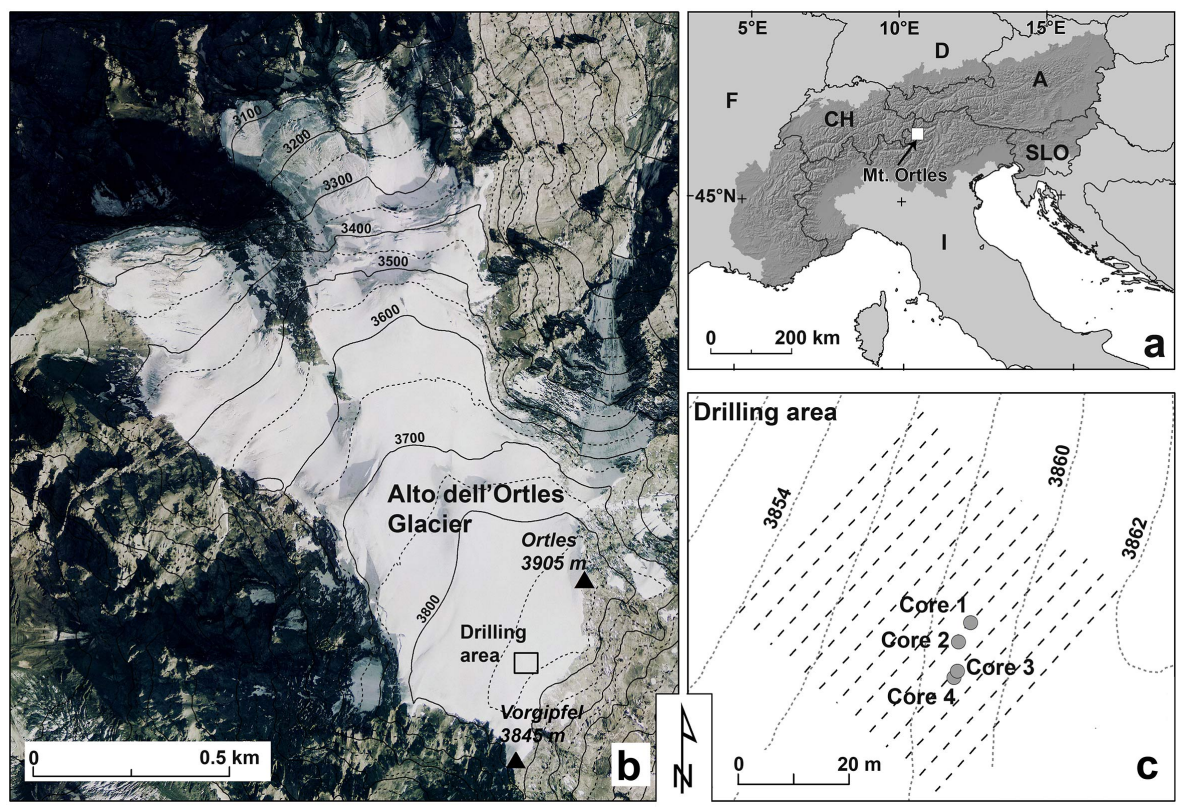

Figure 1. (a) Geographic location of Mt. Ortles. (b) Map of the Alto dell'Ortles glacier (South Tyrol, Italy), including the area (box) where the drilling operation was conducted during September-October 2011. (c) Detailed map of the drilling site, including (i) the specific locations where the four cores were extracted and (ii) the traces of the detailed ground penetration radar (GPR) survey performed in July 2013.

\subsection{Current dynamic}

\subsubsection{Elevation changes}

Comparison of terrestrial photographs of Alto dell'Ortles taken in 2010 and during the period from 1900 to 1930 (Fig. 2), suggests a thinning of $8-10 \mathrm{~m}$ at the drilling site. Comparison of digital terrain models (DTMs) obtained from topographic maps created in 1962 and 1984 (obtained by aerial photogrammetry and provided by the Istituto Geografico Militare and Province of Bolzano, respectively) and from lidar surveys in 2005 and 2013 (provided by the Province of Bolzano and by the Institute of Atmospheric and Cryospheric Sciences, University of Innsbruck; Galos et al., 2015) indicate a major thinning at the drilling site from 1962 to $1984(-25.0 \pm 4.7 \mathrm{~m})$. From 1984 to 2005 thickening prevailed $(+10.5 \pm 7.9 \mathrm{~m})$, followed by minor elevation changes from 2005 to $2013(-0.7 \pm 1.0 \mathrm{~m})$. More extended analyses covering the upper $50 \mathrm{~m}$ of the glacier Alto dell'Ortles, which includes the drilling site, indicate that thinning was widespread from 1962 to $1984(-9.5 \pm 4.7 \mathrm{~m})$ in the upper part of this glacier, followed by rather stationary conditions $(-1.5 \pm 0.3 \mathrm{~m})$ between 1984 and 2013 .

These observations indicate that (i) the upper part of Alto dell'Ortles was subject to significant elevation changes during the last decades; (ii) the drilling site itself experienced even larger elevation changes; and (iii) these elevation changes are not directly linked to atmospheric changes (e.g. summer atmospheric warming and surface glacier ablation). It is indeed remarkable that while the site thinned dur- ing the relatively cold period between the 1960s and 1980s, most glaciers at lower altitude expanded in this geographic area (Carturan et al., 2013 and references therein). Local elevation changes at the drilling site likely result from the interplay of glacier dynamics and spatial variability of ablation and, notably at this high-elevation site, snow accumulation and redistribution by the wind.

\subsubsection{Surface and internal dynamics}

A borehole displacement of $3.2 \mathrm{~m} \mathrm{yr}^{-1}$ over 1.7 years (5 October 2011-1 July 2013) was determined at the glacier surface by means of differential GPS measurements (Fig. 3). However, the glacial flow was not constant during this period as it varied between $3.7 \mathrm{~m} \mathrm{yr}^{-1}$ (5 October 2011-7 September 2012) and $2.6 \mathrm{~m} \mathrm{yr}^{-1}$ (7 September 2012-1 July 2013), suggesting a seasonal variability characterized by a higher flow in summer than in winter.

The direction of the measured displacement of the boreholes and the variability of the glacial flow during the observed periods are consistent with (i) glacier flow lines originating from the southern flank of Mt. Ortles, whose summit is located $270 \mathrm{~m}$ uphill from the drill site (Fig. 3); and (ii) basal sliding of the glacier bed lubricated by summer meltwater, perhaps percolated from the outcrops of bedrock located uphill from the drilling site. The surface flow lines have been inferred from a DTM obtained with a lidar survey performed during the 2011 ice core drilling campaign, using the flow accumulation tool of ESRI ArcMap ${ }^{\mathrm{TM}}$. Importantly, this analysis also shows that the drilling site was located at or in very 


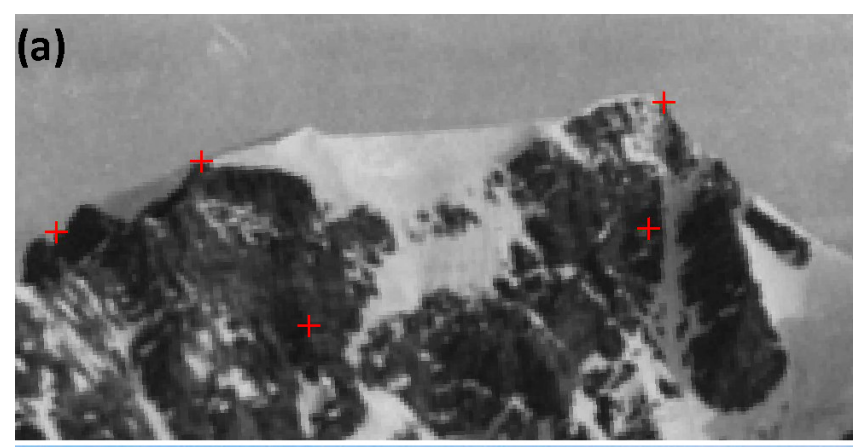

(b)

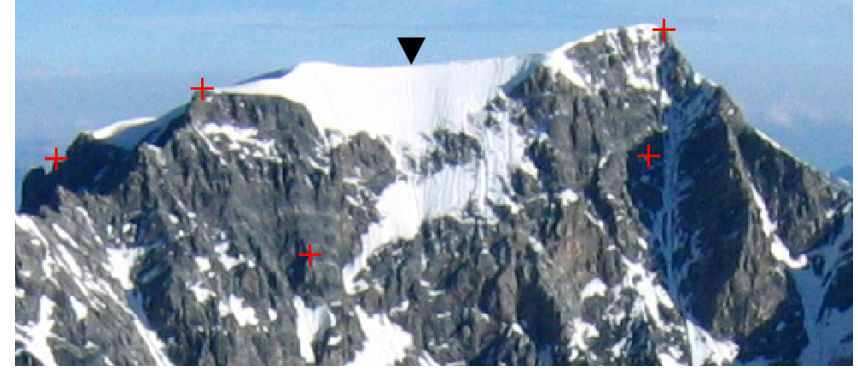

Figure 2. Comparison of terrestrial photographs of Mt. Ortles taken from the summit of Gran Zebrù $(3851 \mathrm{~m})$ (a) during the years 1900-1930 (http://www.montagnedifoto.com/, last access 16 March 2016) and (b) on the 4 July 2010 (photo: Roberto Seppi). The triangle in panel (b) shows the position of the 2011 drilling site. The four symbols $(+)$ indicate the reference points used for co-registering the two photos (ESRI ArcMap ${ }^{\mathrm{TM}}$ ) before estimating the thickness variation at the drilling site during this period.

close proximity to the ice divide (as derived from the surface topography, Fig. 3).

In order to infer the internal dynamics of the glacier, inclinometric measurements were performed in borehole no. 2 43 days after the end of the drilling operation (5 October17 November 2011). Further measurements were not possible because of the rupture of the pipe (or the formation of an internal ice lens) at $25 \mathrm{~m}$ depth. Uncertainty of this measure is $\pm 6 \mathrm{~mm} / 25 \mathrm{~m}$. A cumulative displacement of $277 \mathrm{~mm}$ $\left(2.4 \mathrm{~m} \mathrm{yr}^{-1}\right)$ relative to the bottom part of the inclinometer was observed on the glacier surface (Fig. 4). We also note that the glacier flow decreased linearly with depth, which is inconsistent with the velocity fields typically recorded within glaciers frozen at the bed (Paterson, 1999). While the relative inclinometric measurement does not necessarily imply a net basal sliding of the drilling site, it does indicate that currently ice layers located next to bedrock are dynamically active $\left(38 \mathrm{~mm}\left(0.3 \mathrm{~m} \mathrm{yr}^{-1}\right)\right.$ at $65 \mathrm{~m} ; 18 \mathrm{~mm}\left(0.2 \mathrm{~m} \mathrm{yr}^{-1}\right)$ at $70 \mathrm{~m}$ ). This information is important in order to evaluate the age of the basal ice (see discussion in Sect. 6.2).

\subsection{Bedrock topography}

Ground penetrating radar (GPR) was used to determine the bedrock topography (e.g. Binder et al., 2009; Moran et al., 2000 ) and to infer information about possible englacial features (e.g. Blindow and Thyssen, 1986; Konrad et al., 2013). GPR profiles of $50 \mathrm{MHz}$ were collected with a GSSI SIR 3000 system during July 2013. This spatial survey focused on a region of $50 \times 50 \mathrm{~m}$, including the four 2011 boreholes with an inter-profile distance of $4 \mathrm{~m}$ (Fig. 1c). Based on the available continuous snow/firn/ice density data from a snow pit and from borehole no. 2 (BH2), a 1-D velocity function was derived from the correlation between snow/ice density and dielectric permittivity by Kovacs et al. (1995). The twoway travel times (TWTs) chosen were converted to depth with the 1-D velocity function, and interpolated to continuous surfaces.

The reflection horizon at TWTs of $800-900 \mathrm{~ns}(\sim 75-$ $85 \mathrm{~m}$ ) was interpreted as bedrock. For BH1, BH2 and BH3 there is a good correspondence (within $1 \mathrm{~m}$ ) between the GPR-derived ice thicknesses and the ice core lengths (Fig. 5). The GPR-derived ice depth for BH4 indicated that the ice core drilling was stopped $\sim 15 \mathrm{~m}$ from bedrock. Since the applied snow/ice density-dielectric permittivity correlation is valid for dry polar conditions, this confirms a dry and cold glacial body at the drilling site. Figure 5 shows orthogonal profile slices through the four boreholes according to the coordinate system displayed in Fig. 6.

A continuous internal layer was identified $20-40 \mathrm{~m}$ above the bedrock (Fig. 5). The internal layer could be tracked throughout the investigated area, which suggested an isochronical origin. Two close melt ice layers at a depth of about $45 \mathrm{~m}$ corresponded well with this spatially continuous englacial reflection. The inclination of this melt layer is consistent with the higher $(+200 \mathrm{~mm}$ w.e. $)$ modern annual snow accumulation $(1000 \mathrm{~mm}$ w.e.) observed on the left side (Fig. 5, X-profiles) of the drilling site at $3830 \mathrm{~m}$ (Festi et al., 2015). It is likely that surface snow was blown away from the ice ridge and redeposited further down the slope. Thus the steep isochrone suggests that the oldest ice of the glacier can be found on the right side (Fig. 5, X-profiles), which is under the ice divide. Alternatively, it indicates that the oldest ice can be found at higher depth resolution below the ice divide.

Detailed bedrock topography at the drill site, as obtained by spatial interpolation of GPR point measurements, is illustrated in Fig. 6. We note that the boreholes reached bedrock near a $\sim 10 \mathrm{~m}$ step located between the drilling site and the Vorgipfel (Figs. 1, 5, and 6). However, this feature is only on one side of the drilling site, and thus we conclude that while this morphological feature may have facilitated the in situ retention of old bottom ice, it is unlikely to have caused a complete dynamical entrapment and the consequent formation of fossil ice decoupled from the upper stratigraphic sequence, 


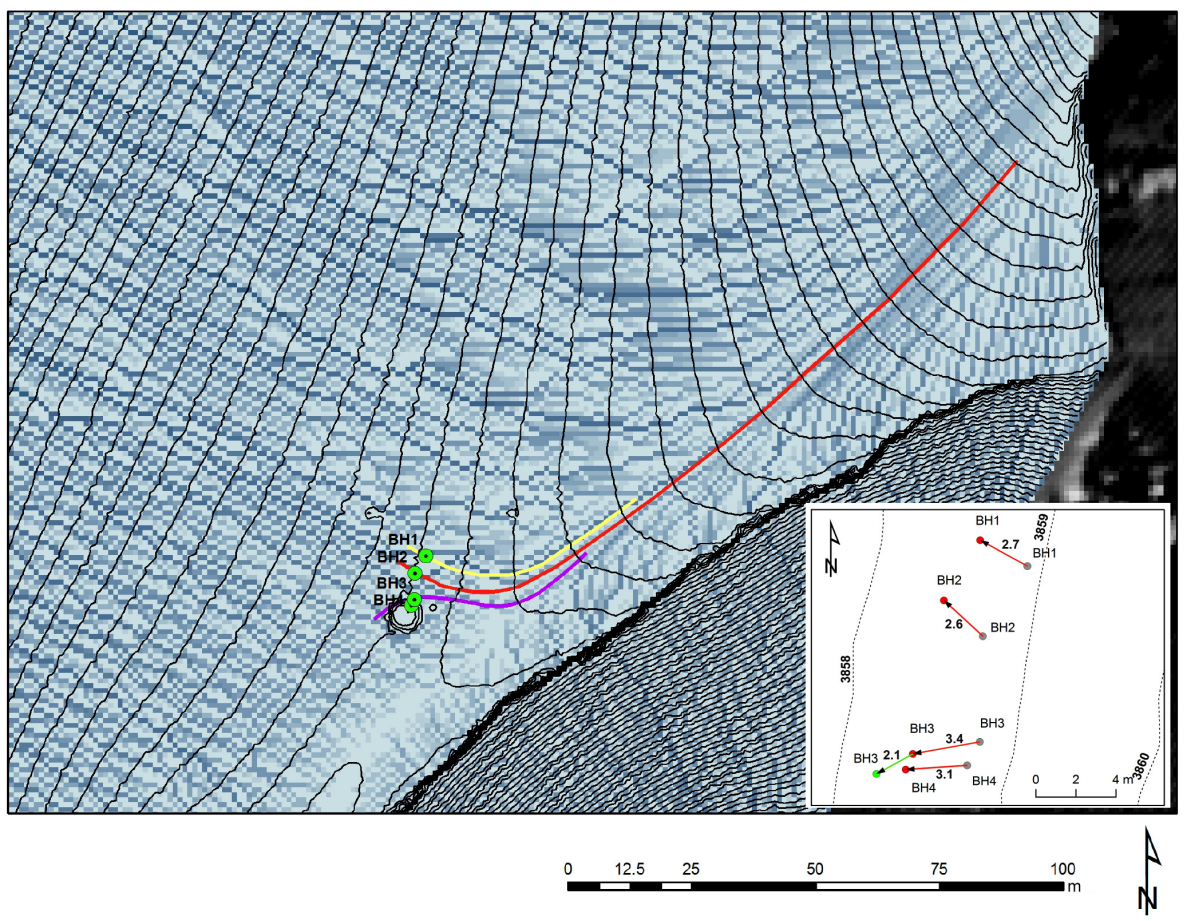

Figure 3. Reconstructed flow lines and borehole displacements over time. The surface topography of the drill site was obtained from a lidar survey conducted during the 2011 campaign (note that the contour lines of the drilling dome are visible). Inset: the displacement between 5 October 2011 and 7 September 2012 is shown in red, while the shift between 7 September 2012 and 1 July 2013 is in green (borehole no. 3 only). The values indicate the displacement (in metres) measured by GPS during these two periods.

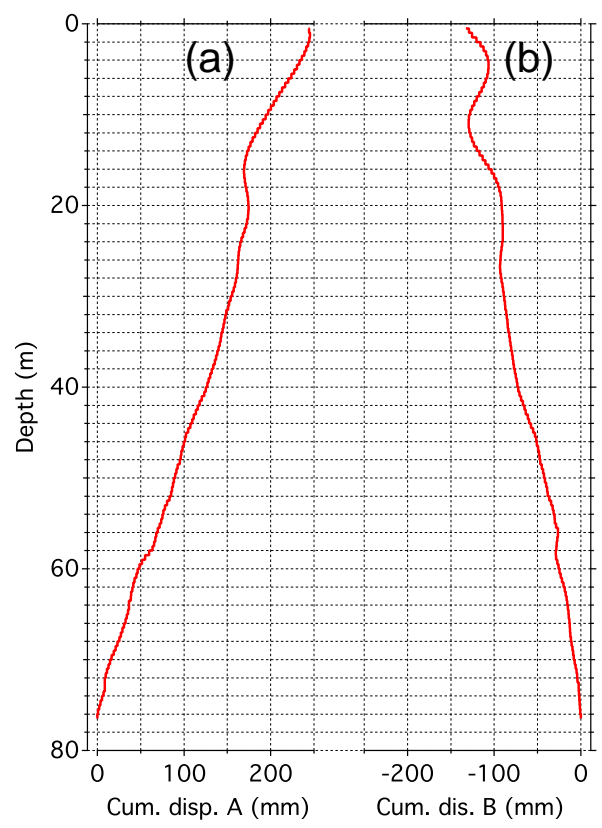

Figure 4. Relative cumulative displacement of borehole no. 2 along the two axes $\left(\mathrm{A}: 340^{\circ} \mathrm{N} ; \mathrm{B}: 70^{\circ} \mathrm{N}\right)$ during the 43 days after the end of the 2011 drilling operation. The cumulative displacement is relative as it uses the bottom portion of the inclinometer as a reference (not the bedrock). which is also implied by the ice flow observed near bedrock (Fig. 4).

\section{Ice core characteristics}

The four cores were drilled on Alto dell' Ortles within $\sim 10 \mathrm{~m}$ (Fig. 1), reaching final logged depths of $73.53 \mathrm{~m}$ (no. 1), $74.88 \mathrm{~m}$ (no. 2), $74.83 \mathrm{~m}$ (no. 3) and $61 \mathrm{~m}$ (no. 4). The drilling of core no. 4 was stopped for technical issues at a depth $\sim 15 \mathrm{~m}$ above bedrock as determined by GPR (see previous section). It has been stored intact for possible future complementary analysis. Likewise, the drilling of core no. 1 stopped at $73.53 \mathrm{~m}$ just short of bedrock because of technical issues. On the other hand, it was obvious that cores no. 2 and no. 3 did reach bedrock since further penetration was not possible and damage to the drill cutters was observed. The comparable final logged depths of core no. 1, no. 2 and no. 3 $(73.53,74.88$ and $74.83 \mathrm{~m})$ are in close agreement with the glacier thickness $(75 \mathrm{~m}$ ) as determined by GPR before (2009) (Gabrielli et al., 2010) and after (2013) the drilling operation (see previous section).

Consistent with the geology of the Mt. Ortles summit, a few limestone rock particles and pebbles were observed in the deepest sections of cores no. 1, no. 2 and no. 3 within $\sim 1 \mathrm{~m}$ of bedrock, providing visible evidence for the bed ma- 

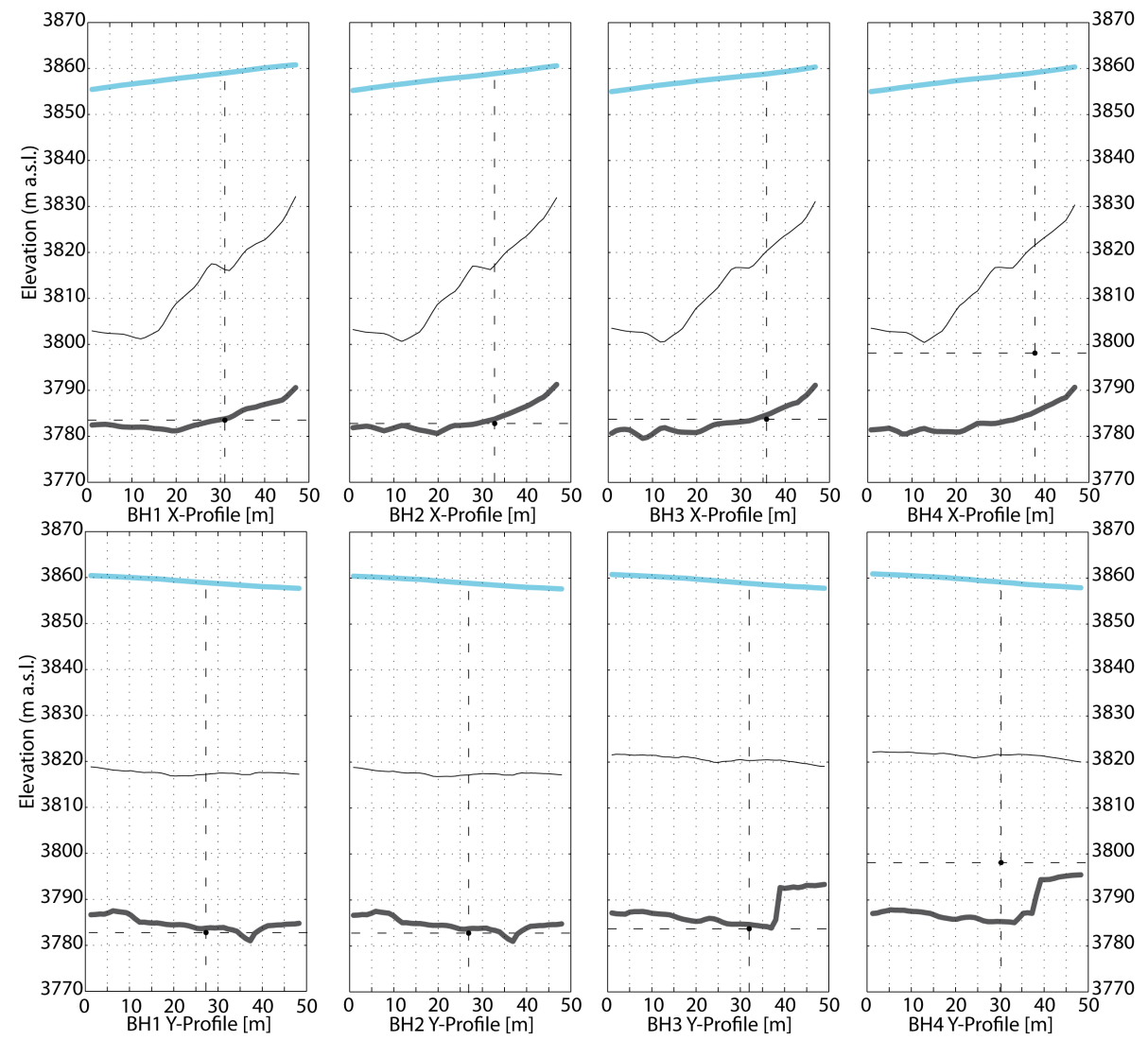

Figure 5. The top images illustrate the GPR $X$-profiles (constant $y$ coordinate) and $Y$-profiles (constant $x$ coordinate) through the locations of boreholes no. 1-4 (see also Fig. 6). Two-dimensional slices of the interpolated bedrock surfaces (thick grey line) and a possible englacial layer (thin grey line) are shown. The thick blue line indicates the glacier surface. Black dots show the logged depths for boreholes no. 1-4.

terial in the bottom ice. In core no. 2 a single large pebble $(\sim 1 \mathrm{~cm})$ was observed $2.77 \mathrm{~m}$ above bedrock. This was either entrained from the bed or from the glacier surface because of the short distance $(\sim 250 \mathrm{~m})$ of the drilling site from the rock outcrops of the Mt. Ortles summit.

Density measurements of cores no. 1, no. 2 and no. 3 indicate a firn/ice transition at $\sim 30 \mathrm{~m}$ depth (Fig. 7), with a measured average ice density of $882 \mathrm{~kg} \mathrm{~m}^{-3}$. The air bubbles entrapped within the ice layers throughout the core range from a few millimetres to less than $\sim 1 \mathrm{~mm}$ in diameter. Elongated air bubbles (up to $10-15 \mathrm{~mm}$ ) are widespread through the cores, confirming that flow is a significant component of the ice dynamics of this drilling site (Gabrielli et al., 2012).

Direct observations of the three cores were performed and borehole images were obtained from a $360^{\circ}$ continuousimaging scan of borehole no. 1 (Optical Televiewer, Advanced Logic Technology, Luxembourg). As light reflectance is determined by the concentration and size of air bubbles, this technique highlights the core layers and the presence of ice lenses (melt layers). Horizontal to tilted $\left(10-20^{\circ}\right)$ bubblefree ice lenses are present throughout the entire lengths of the cores, where the angles may reflect, at least in part, the tilt of the basal slope. The cumulative thickness of the ice lenses constitutes $\sim 20 \%$ of the entire length of the firn portion (when expressed in ice equivalent), $\sim 15 \%$ of the glacier ice between 30 and $55 \mathrm{~m}$ and $\sim 5 \%$ between 55 and $65 \mathrm{~m}$ depth (Gabrielli et al., 2012).

Borehole images of core no. 1 also suggest strong ice layer thinning from 60 to $65 \mathrm{~m}$ depth to the basal ice (Fig. 7). In this case we interpret the low reflectance of this basal ice as a consequence of the bubbles shrinking due to the overburden pressure over thousands of years (see Sect. 4.3). The digital red index associated with the borehole images (this expresses numerically the red component of each pixel that displays colours as a combination of red, green and blue; RGB colour code) suggests that this transition does not occur abruptly (as expected in the case of a physical hiatus) but instead over $\sim 5 \mathrm{~m}$, perhaps indicating a continuous change of the physical properties of the ice over time. This observation is also important in order to evaluate the possible presence of a decoupled fossil ice portion near the bedrock. 


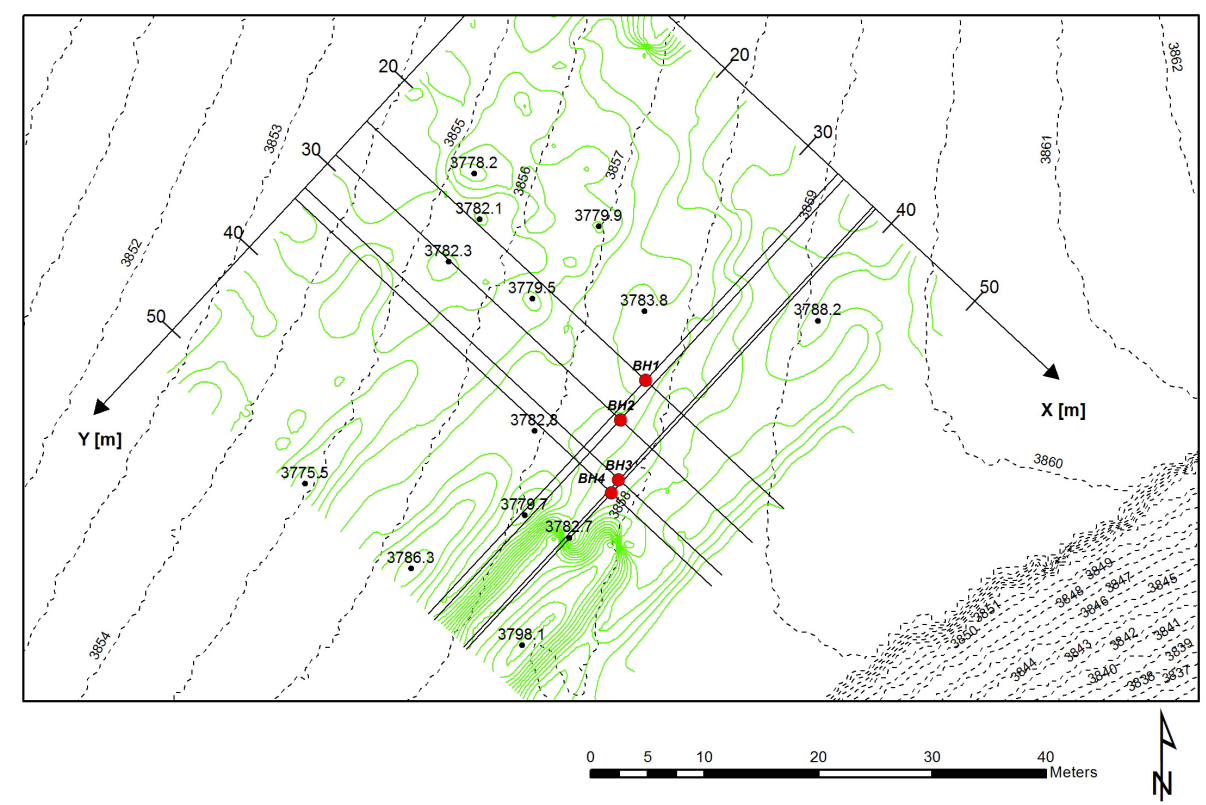

Figure 6. Bedrock contours and surface topography of the 2011 ice core drill site. Data were obtained during the 2013 GPR and lidar surveys, respectively. Bedrock contours are shown in green, while the surface topography is displayed in black. The positions where the four cores were extracted in 2011 are shown as filled red circles. The GPR $X$-profiles (constant $y$ coordinate) and $Y$-profiles (constant $x$ coordinate) through the locations of boreholes no. 1-4 are also shown (see also Fig. 5).

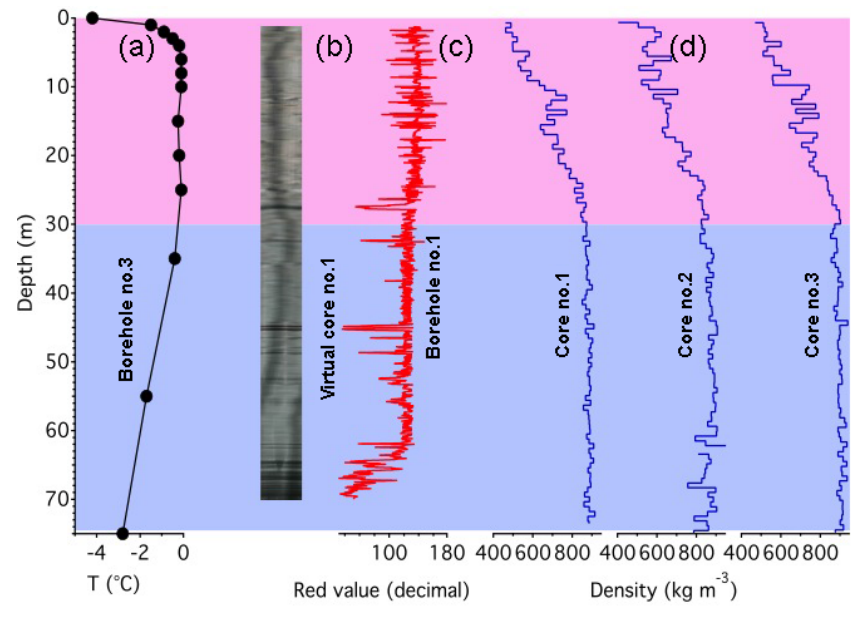

Figure 7. Physical characteristics of the Mt. Ortles cores. The temperate firn portion is enclosed in red shading, while the cold ice is in blue. (a) Borehole no. 3 temperatures recorded 43 days after the end of the drilling operations (from Gabrielli et al., 2012). (b) Virtual image of core no. 1 reconstructed from $360^{\circ}$ Televiewer visual scanning of borehole no. 1. (c) Red component of the RGB digital signal obtained by means of visual scanning. High values indicate higher light reflection. (d) Densities of the Mt. Ortles ice cores no. 1, no. 2 and no. 3 .

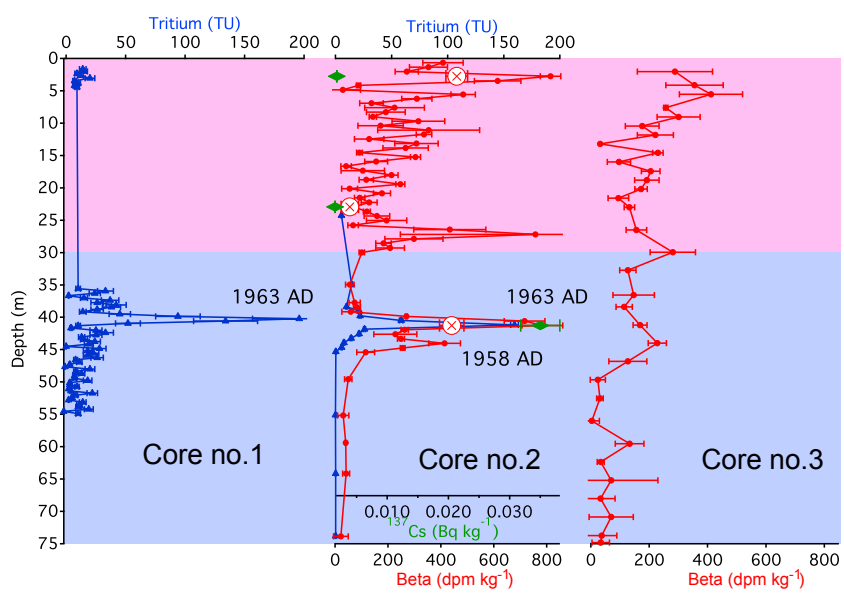

Figure 8. Fission products determined in the Mt. Ortles cores no. 1, no. 2 and no. 3. The temperate firn portion is enclosed in red shading, while the cold ice is in blue. Tritium is depicted by blue triangles, beta emissions by red dots (BPCRC) or red crosses (LGGE) and ${ }^{137} \mathrm{Cs}$ by green diamonds. Beta emissions in cores no. 2 and no. 3 are determined at different resolutions depending on the sample mass available. 


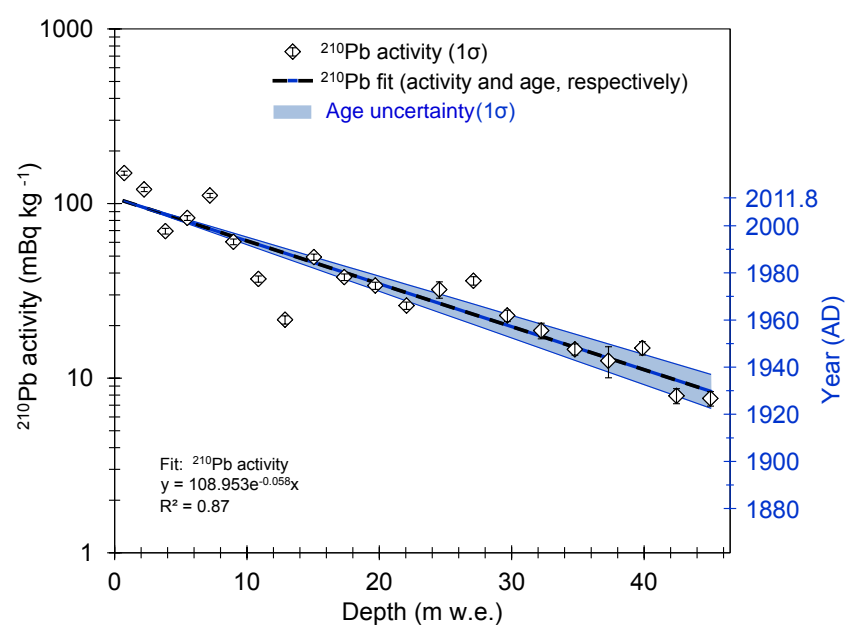

Figure 9. Measured ${ }^{210} \mathrm{~Pb}$ activity (left $y$ axis, logarithmic scale) and calculated age (right $y$ axis) vs. depth (in metres of water equivalent) relationship in the Mt. Ortles core no. 2. The fit is also reported for ${ }^{210} \mathrm{~Pb}$ activity (logarithmic, black) and age (linear, blue); the latter is shown with its $1 \sigma$ confidence interval (in blue).

\section{Ice core samples analysis}

\subsection{Fission products}

\subsubsection{Beta activity and tritium}

Depending on the ice mass available, analyses of beta activity (Byrd Polar and Climate Research Center, BPCRC) and tritium (University of Bern and University of Venice) were performed with various degrees of continuity and resolution in various sections of the cores using established methods (Maggi et al., 1998; Schotterer et al., 1998; van der Veen et al., 2001) (Fig. 8). Three sections from core no. 2 (2.75, 22.95 and $41.27 \mathrm{~m}$ ) were reanalysed for beta activity at the Laboratory of Glaciology and Geophysics of the Environment (LGGE) in Grenoble, France, by means of a Berthold LB770-2 gas-flow proportional counter $\left(\mathrm{Ar} / \mathrm{CH}_{4}\right.$ gas) (Magand, 2009; Pourchet et al., 2003; Vimeux et al., 2008), showing variations that are consistent with those determined at BPCRC (Fig. 8).

A well-defined peak of beta and tritium activity can be observed at $41 \mathrm{~m}$ depth, indicating the 1963 radioactive horizon resulting from nuclear weapon testing, which is consistent with ${ }^{210} \mathrm{~Pb}$ dating (see below). The match between the tritium (entrained in the ice matrix) and beta emission (emitted by ions such as ${ }^{90} \mathrm{Sr}$ ) peaks in core no. 2 suggests that post-depositional effects due to meltwater percolation were negligible from the time of the deposition of this radioactive layer (1963) until it was entrained below the firn-ice transition. This is also a preliminary indication that the chemical stratigraphy in the firn and in the ice was preserved before the onset of the exceptional current warming (1980 in this area) and the linked surface melting and meltwater percolation
(Gabrielli et al., 2010, 2012). Scrutiny of the well-resolved beta record in core no. 2 indicates a secondary beta emission peak at $44 \mathrm{~m}$ depth, likely resulting from the widely reported 1955-1958 thermonuclear tests (Gabrieli et al., 2011).

Evidence of the radioactive fallout from the 9 March 2011 Fukushima nuclear plant accident is observed in the shallow spring-summer 2011 layer (Fig. 8). In this case, while tritium levels remain low, beta activity reaches values that are comparable to the residual radioactivity released by the ice layers contaminated by the atmospheric nuclear tests of the 1950s and the beginning of the 1960s. Glaciological evidence for the Fukushima radioactive fallout has already been reported from Tibetan Plateau (Wang et al., 2015) and Arctic (Ezerinskis et al., 2014) snow samples. Our data from the eastern Alps are consistent with the clearly detectable Fukushima radioactive fallout widely observed in Europe (Masson et al., 2011), including the northern Italian city of Milan (Clemenza et al., 2012).

An additional peak of beta activity can be observed in the Mt. Ortles cores at $\sim 28 \mathrm{~m}$ of depth (Fig. 8 ), near a thick ice lens immediately above the firn ice transition $(\sim 30 \mathrm{~m})$. This signal does not seem to be directly related to the 1986 Chernobyl radioactive fallout as its timing is inconsistent with the ${ }^{210} \mathrm{~Pb}$ age determined at this depth $(1979.5 \pm 3$; see Sect. 4.2). It is more likely that percolating summer meltwater transported Chernobyl radionuclides through the porous temperate firn from their actual deposition layers (see next section) down to $\sim 28 \mathrm{~m}$ where at least part of the water refroze and the radionuclides were accumulated. This process also suggests that the chemical stratigraphy is not well preserved in the firn portion of the Mt. Ortles cores.

\subsection{2 ${ }^{137} \mathrm{Cs}$}

The three sections analysed for beta emissions at LGGE (see previous section) were also analysed by a very low background germanium planar detector at the Laboratoire Souterrain de Modane (LSM - 4800 water equivalent) in France (Loaiza et al., 2011). These measurements were below the detection limit with the exception of the section at $41.27 \mathrm{~m}$ (1963), which showed a non-decay-corrected activity of $0.035 \pm 0.003\left(\mathrm{~Bq} \mathrm{~kg}^{-1}\right)$ for ${ }^{137} \mathrm{Cs}$. This result is consistent with ${ }^{137} \mathrm{Cs}$ values typically linked to the 1963 radioactive deposition (United Nations Scientific Committee on the Effects of Atomic Radiation, 2000).

The undetected ${ }^{137} \mathrm{Cs}$ in the $22.95 \mathrm{~m}$ depth layers ( 1986-1987 according to ${ }^{210} \mathrm{~Pb}$ dating, see next section) is notable, taking the large ${ }^{137} \mathrm{Cs}$ quantities released in the European atmosphere during the 1986 Chernobyl accident into account (United Nations Scientific Committee on the Effects of Atomic Radiation, 2000). This provides additional support for the idea of the occurrence of post-positional effects due to abundant multi-year meltwater percolation through the firn during the recent warm summers (Gabrielli et al., 2010). 
The very low ${ }^{137} \mathrm{Cs}$ values measured in Mt. Ortles snow within the top $2.75 \mathrm{~m}$ (spring-summer 2011) after the Fukushima accident are consistent with the low levels measured in aerosols over Europe, which is 3 to 4 orders of magnitude lower than activity levels encountered after the Chernobyl event (Mietelski et al., 2014; Povinec et al., 2013). Therefore, it is more likely that the beta activity detected in the Mt. Ortles shallow 2011 snow layer was the product of long-range transport of other Fukushima-derived radionuclides, especially ${ }^{131}$ I (Clemenza et al., 2012; Mietelski et al., 2014; Povinec et al., 2013; Lin et al., 2015). Given the short half-life of ${ }^{131}$ I ( 8 days), it might be expected that this layer could be only a short-term glaciological reference.

\section{$4.2{ }^{210} \mathrm{~Pb}$}

${ }^{210} \mathrm{~Pb}$ activity was determined continuously in core no. 2 between 0 and $58.67 \mathrm{~m}$ depth at a sample resolution of $\sim 2.80 \mathrm{~m}$ length (Table 1) using an established method (Gäggeler et al., 1983; Eichler et al., 2000). The age-depth relationship was derived from the slope of the linear regression of the logarithmic ${ }^{210} \mathrm{~Pb}$ activity as a function of depth in metres of water equivalent (Fig. 9). The $y$ axis intercept $\left(109 \pm 14 \mathrm{mBq} \mathrm{kg}^{-1}\right)$ corresponds to the ${ }^{210} \mathrm{~Pb}$ activity at the surface of the Alto dell'Ortles glacier, and is comparable to values typically observed $\left(\sim 85 \pm 10 \mathrm{mBq} \mathrm{kg}^{-1}\right)$ in highaltitude glaciers in the Alps (Eichler et al., 2000). At a depth of $41.92 \mathrm{~m}$, the calculated age of $54 \pm 5$ years (1953-1963, $1 \sigma$ range) is consistent with the 1963 beta and tritium activity peak found at $41 \mathrm{~m}$ (see previous sections). The age of the lowest sample (bottom depth $58.67 \mathrm{~m}$ ) dated by ${ }^{210} \mathrm{~Pb}$ is $82 \pm 7$ years (1923-1937, $1 \sigma$ range).

\section{$4.3{ }^{14} \mathrm{C}$ analysis}

Four large $(\sim 1 \mathrm{~kg})$ samples from Mt. Ortles cores no. 1 (68.96 and $72.48 \mathrm{~m}$ ) and no. 3 (71.57 and $74.47 \mathrm{~m}$ ) (Table 2) were selected for ${ }^{14} \mathrm{C}$ dating using a method based on ${ }^{14} \mathrm{C}$ determination in the water-insoluble organic carbon fraction (WIOC) of the aerosols in the ice (Jenk et al., 2006, 2007, 2009; Sigl et al., 2009). Core no. 2 was not sampled because sufficient ice volume was not available. Each ice section was divided into three subsamples (top, middle and bottom), which were filtered separately and analysed. For the section at $72.48 \mathrm{~m}$ from core no. 1, the amount of filtered WIOC from the first subsample was estimated to be insufficient, and therefore the three subsamples were filtered together, resulting in a total ice volume exceeding our standard dimensions, possibly introducing a larger blank because of the modified treatment (i.e. increased potential for contamination due to a higher number of steps during sample processing).

${ }^{14} \mathrm{C}$ analyses were conducted using the compact radiocarbon Accelerator Mass Spectrometer (AMS) system "MICADAS" at the University of Bern (LARA laboratory). For details about sample preparation, WIOC separation, blank correction and calculation of $\mathrm{F}^{14} \mathrm{C}$, see Uglietti et al. (2016). The conventional ${ }^{14} \mathrm{C}$ ages were calibrated using OxCal v4.2.4 software (Bronk Ramsey and Lee, 2013) with the IntCal13 calibration curve (Reimer et al., 2013). Dates are provided as radiocarbon ages (yrs BP), calibrated radiocarbon ages (yrs cal BP) or as years before the date of sampling, with 2012 being the closest approximation of a full year (yrs b2012 $=2012-1950+$ yrs cal BP). Average values $(\mu)$ are presented with a 1 sigma $(\sigma)$ uncertainty.

The $\mathrm{F}^{14} \mathrm{C}$ results obtained for the three subsamples (top, middle, bottom) of section $98 \mathrm{~b}$ at $68.96 \mathrm{~m}$ (core no. 1) and 102 at $71.57 \mathrm{~m}$ (core no. 3), respectively, were combined to obtain the most reliable ages representative of the mid-depth of these sections (mean value of the three subsamples with $1 \sigma$ standard error) with the data-supported assumption of a negligible age spread within these two sections. The resulting mean calibrated ages were $595 \pm 205 \mathrm{yrs}$ cal BP and $1521 \pm 286$ yrs cal BP, respectively (Table 2 ). On the other hand, the three subsamples from the deepest section of core no. $3(74.47 \mathrm{~m})$ dated with an age of $4173 \pm 523,5178 \pm 530$, and $6742 \pm 365 \mathrm{yrs}$ cal BP, respectively, indicate very strong glacier thinning close to bedrock, and were thus treated as individual dating horizons. The analysis of the single sample from the section at $72.48 \mathrm{~m}$ (core no. 1) provided an age of $517 \pm 291 \mathrm{yrs}$ cal BP that would represent a chronological inversion with respect to all the other ${ }^{14} \mathrm{C}$ ages. Considering the above-mentioned increased risk of contamination during sample preparation this age value was disregarded.

${ }^{14} \mathrm{C}$ analyses of a larch leaf found at $73.25 \mathrm{~m}$ depth in core no. 1 were performed by AMS at the National Ocean Sciences Accelerator Mass Spectrometry facility at the Woods Hole Oceanographic Institution. This provided an additional, conventionally derived ${ }^{14} \mathrm{C}$ age of $2612 \pm 101$ yrs cal BP, which is stratigraphically and chronologically consistent with the WIOC ${ }^{14} \mathrm{C}$ ages of $1521 \pm 286$ and $4173 \pm 523 \mathrm{yrs}$ cal BP obtained from core no. 3 at 71.57 and $74.02 \mathrm{~m}$ of depth, respectively (Table 2). Stratigraphic consistency also remains valid when a common depth scale for the three cores is adopted (see next section).

\section{Ice core chronology}

\subsection{Depth-scale alignment}

Cores no. 1, no. 2 and no. 3 were aligned on the same depth scale (Fig. 10) by matching their stable isotope records (smoothed by three-sample moving averages), which were determined at the BPCRC (cores no. 2 and no. 3 ) and at the University of Venice (core no. 1). Core no. 2 was chosen as the reference core because it was analysed at the highest resolution (3100 samples; 2220 for core no. 1 and 1038 for core no. 3) and because it is also the longest core $(74.88 \mathrm{~m}$ vs. $73.53,74.83 \mathrm{~m}$ for core no. 1 and no. 3). Similar fea- 
Table 1. ${ }^{210} \mathrm{~Pb}$ dating. Determinations of ${ }^{210} \mathrm{~Pb}$ activity and calculated ages for the upper part of the Mt. Ortles ice core no. $2(0-58.67 \mathrm{~m})$. Note the notation used for ages in yrs b2012.

\begin{tabular}{|c|c|c|c|c|c|c|c|c|c|}
\hline $\begin{array}{l}\text { Top depth } \\
\text { (m) }\end{array}$ & $\begin{array}{l}\text { Bottom depth } \\
\text { (m) }\end{array}$ & $\begin{array}{l}\text { Top depth } \\
\text { (m w.e.) }\end{array}$ & $\begin{array}{l}\text { Bottom depth } \\
\text { (m w.e.) }\end{array}$ & $\begin{array}{l}\text { Activity in } 2011 \\
\text { (mBq kg) }\end{array}$ & $\begin{array}{l}\text { Uncertainty } \\
\left(\mathrm{mBq} \mathrm{kg}^{-1}\right)\end{array}$ & $\begin{array}{l}\text { Age } \\
\text { (yrs b2012) }\end{array}$ & $\begin{array}{l}\text { Lower age }-1 \sigma \\
(\mathrm{yrs} b 2012)\end{array}$ & $\begin{array}{l}\text { Upper age }+1 \sigma \\
(\text { yrs b2012) }\end{array}$ & $\begin{array}{l}\text { Age } \\
(\mathrm{AD})\end{array}$ \\
\hline 0.00 & 2.75 & 0.00 & 1.46 & 149.4 & 3.9 & 1.5 & 1.4 & 1.6 & 2010.5 \\
\hline 2.75 & 5.56 & 1.46 & 3.02 & 120.4 & 3.4 & 4.3 & 3.9 & 4.6 & 2007.7 \\
\hline 5.56 & 8.31 & 3.02 & 4.66 & 69.5 & 2.6 & 7.2 & 6.6 & 7.8 & 2004.8 \\
\hline 8.31 & 11.09 & 4.66 & 6.33 & 82.7 & 2.7 & 10.2 & 9.3 & 11.1 & 2001.8 \\
\hline 11.09 & 13.85 & 6.33 & 8.08 & 111.3 & 3.1 & 13.3 & 12.1 & 14.5 & 1998.7 \\
\hline 13.85 & 16.64 & 8.08 & 9.89 & 60.4 & 2.2 & 16.6 & 15.1 & 18.0 & 1995.4 \\
\hline 16.64 & 19.44 & 9.89 & 11.84 & 37.0 & 1.5 & 20.0 & 18.2 & 21.7 & 1992.0 \\
\hline 19.44 & 22.25 & 11.84 & 13.92 & 21.6 & 1.2 & 23.6 & 21.6 & 25.7 & 1988.4 \\
\hline 22.25 & 25.05 & 13.92 & 16.20 & 49.3 & 2.1 & 27.6 & 25.2 & 30.1 & 1984.4 \\
\hline 25.05 & 27.88 & 16.20 & 18.52 & 37.8 & 1.7 & 31.8 & 29.0 & 34.6 & 1980.2 \\
\hline 27.88 & 30.68 & 18.52 & 20.88 & 33.9 & 1.6 & 36.1 & 32.9 & 39.3 & 1975.9 \\
\hline 30.68 & 33.52 & 20.88 & 23.24 & 26.0 & 1.3 & 40.4 & 36.8 & 43.9 & 1971.6 \\
\hline 33.52 & 36.34 & 23.24 & 25.83 & 32.2 & 3.5 & 44.9 & 40.9 & 48.8 & 1967.1 \\
\hline 36.34 & 39.15 & 25.83 & 28.40 & 36.1 & 2.0 & 49.6 & 45.2 & 54.0 & 1962.4 \\
\hline 39.15 & 41.92 & 28.40 & 30.94 & 22.8 & 1.7 & 54.2 & 49.4 & 59.0 & 1957.8 \\
\hline 41.92 & 44.74 & 30.94 & 33.52 & 18.7 & 1.9 & 58.9 & 53.6 & 64.1 & 1953.1 \\
\hline 44.74 & 47.48 & 33.52 & 36.03 & 14.6 & 1.1 & 63.5 & 57.9 & 69.1 & 1948.5 \\
\hline 47.48 & 50.27 & 36.03 & 38.59 & 12.6 & 2.5 & 68.1 & 62.1 & 74.2 & 1943.9 \\
\hline 50.27 & 53.07 & 38.59 & 41.16 & 14.9 & 1.3 & 72.8 & 66.3 & 79.3 & 1939.2 \\
\hline 53.07 & 55.88 & 41.16 & 43.74 & 7.9 & 0.8 & 77.5 & 70.6 & 84.4 & 1934.5 \\
\hline 55.88 & 58.67 & 43.74 & 46.29 & 7.6 & 0.7 & 82.1 & 74.8 & 89.5 & 1929.9 \\
\hline
\end{tabular}

Table 2. ${ }^{14} \mathrm{C}$ analyses of the particle organic fraction (WIOC) obtained from the four sections (tubes) of the Mt. Ortles ice cores no. 1 and no. 3. Except for Sect. 103b, the samples were analysed in three subsamples (top, middle, bottom). ${ }^{14} \mathrm{C}$ determination in Sect. $105 \mathrm{~b}$ (core no. 1) refers to a larch leaf that was found in the ice. Samples reported in bold are those also included in Table 3. Note the notation used for calibrated ages in yrs b2012.

\begin{tabular}{|c|c|c|c|c|c|c|c|c|c|c|c|}
\hline $\begin{array}{l}\text { Core } \\
\text { no. }\end{array}$ & $\begin{array}{l}\text { Tube } \\
\text { no. }\end{array}$ & Measure & $\begin{array}{l}\text { Top } \\
\text { depth (m) }\end{array}$ & $\begin{array}{l}\text { Bottom } \\
\text { depth (m) }\end{array}$ & $\begin{array}{l}\text { WIOC } \\
(\mu \mathrm{g})\end{array}$ & $\mathrm{F}^{14} \mathrm{C}$ & $\begin{array}{l}{ }^{14} \mathrm{C} \text { age } \\
\text { (yrs BP) }\end{array}$ & $\begin{array}{l}\text { Cal age } \\
\text { (yrs cal BP) }\end{array}$ & $\begin{array}{l}\mu \mathrm{cal} \text { age } \\
\text { (yrs cal BP) }\end{array}$ & $\begin{array}{l}\mu \mathrm{cal} \text { age } \\
\text { (yrs b2012) }\end{array}$ & $\begin{array}{l}\sigma \\
\text { (years) }\end{array}$ \\
\hline 1 & $98 \mathrm{~b}$ & WIOC & 68.26 & 68.49 & 17.11 & $0.971 \pm 0.024$ & $236 \pm 199$ & $(-4-461)$ & 279 & 341 & 167 \\
\hline 1 & $98 b$ & WIOC & 68.49 & 68.73 & 17.86 & $0.911 \pm 0.021$ & $749 \pm 185$ & $(550-902)$ & 732 & 794 & 163 \\
\hline \multirow[t]{2}{*}{1} & $98 b$ & WIOC & 68.73 & 68.96 & 15.06 & $0.900 \pm 0.024$ & $846 \pm 214$ & (562-974) & 824 & 886 & 192 \\
\hline & \multicolumn{2}{|c|}{$98 \mathrm{~b}$ WIOC $^{\mathrm{b}}$} & 68.26 & 68.96 & & $0.927 \pm 0.025$ & $609 \pm 217$ & (331-790) & 595 & 657 & 205 \\
\hline 3 & 102 & WIOC & 70.87 & 71.14 & 7.98 & $0.784 \pm 0.043$ & $1955 \pm 451$ & $(1395-2431)$ & 2011 & 2073 & 517 \\
\hline 3 & 102 & WIOC & 71.14 & 71.35 & 7.15 & $0.867 \pm 0.065$ & $1146 \pm 602$ & $(537-1720)$ & 1253 & 1315 & 620 \\
\hline \multirow[t]{2}{*}{3} & 102 & WIOC & 71.35 & 71.57 & 13.28 & $0.818 \pm 0.032$ & $1614 \pm 314$ & (1187-1921) & 1590 & 1652 & 347 \\
\hline & \multicolumn{2}{|c|}{102 WIOC $^{b}$} & 70.87 & 71.57 & & $0.823 \pm 0.027$ & $1565 \pm 264$ & $(1262-1818)$ & 1521 & 1583 & 286 \\
\hline 1 & $103 b$ & WIOC & 71.8 & 72.48 & 10.37 & $0.932 \pm 0.037$ & $569 \pm 320$ & (156-903) & 517 & 579 & 291 \\
\hline 1 & $105 b$ & Larch leaf & 73.25 & 73.25 & $68^{\mathrm{a}}$ & $0.728 \pm 0.006$ & $2550 \pm 65$ & $(2500-2752)$ & 2612 & 2674 & 101 \\
\hline 3 & 106 & WIOC & 73.73 & 74.02 & 10.91 & $0.628 \pm 0.031$ & $3737 \pm 397$ & $(3593-4787)$ & 4173 & 4235 & 523 \\
\hline 3 & 106 & WIOC & 74.02 & 74.24 & 11.50 & $0.568 \pm 0.030$ & $4544 \pm 424$ & $(4623-5715)$ & 5178 & 5240 & 530 \\
\hline 3 & 106 & WIOC & 74.24 & 74.47 & 18.47 & $0.481 \pm 0.020$ & $5879 \pm 334$ & $(6354-7156)$ & 6742 & 6804 & 365 \\
\hline
\end{tabular}

a Pure C extracted after combustion.
${ }^{b}$ Combined values from the three subsamples of tubes $98 \mathrm{~b}$ and 102.

tures among the $\delta^{18} \mathrm{O}$ records were matched, and correlation coefficients $(r)$ were calculated using the AnalySeries 2.0.8 software. Seventeen tie points between core no. 2 and no. $1(r=0.72)$ and 14 tie points between core no. 2 and no. $3(r=0.67)$ were used to establish the correspondence between the records. Due to the close proximity of the boreholes, modifications of the original depths of cores no. 1 and no. 3 were consistently within $1 \mathrm{~m}$, which is confirmed by the common stratigraphic control point at $\sim 41 \mathrm{~m}$ (1963 radioactive peak). The only depth interval in which the profiles of the three cores do not match is near the firn/ice transition ( $\sim 30 \mathrm{~m}$ of depth), probably due to the localized differences in the extent of post-depositional effects from meltwater percolation. Nevertheless, the generally good correlation between the matching of the three stable isotopic records is compelling evidence for the stratigraphic consistency of the 


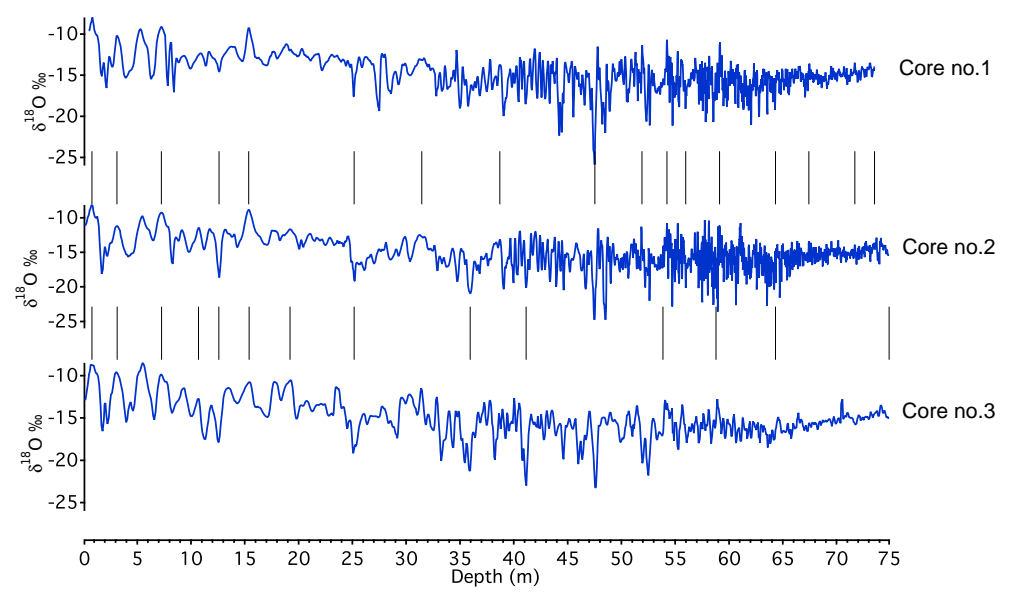

Figure 10. Alignment of the stable isotopic profiles from Mt. Ortles cores no. 1, no. 2 and no. 3 by depth. Vertical bars indicate the points used to tie cores no. 1 and no. 3 to core no. 2 . The latter is used as the reference.

Mt. Ortles cores, and further suggests the preservation of climatic and environmental signals.

\subsection{Depth-age relationship}

Once a common depth scale for the three cores was established, we developed a continuous depth-age relationship by combining the results obtained from the various independent dating methods applied to the three cores. The chronological references we used are summarized in Table 3. When possible, priority was given to the most accurate time references (e.g. 1963 tritium peak instead of the corresponding ${ }^{210} \mathrm{~Pb}$ determinations). Two approaches were attempted: (i) the Thompson 2-parameter model (2-p model) (Thompson et al., 2002) successfully applied to an Alpine ice core from Colle Gnifetti to derive an age-depth relationship based on WIOC ${ }^{14} \mathrm{C}$ dates (Jenk et al., 2009); and (ii) an empirical fitting of the depth age data points (expressed in metres of w.e. and yrs b2012, respectively) by means of a Monte Carlo simulation (2000 simulation runs) (Breitenbach et al., 2012).

A fit by the 2-p model could not be achieved (not shown) because the degrees of freedom allowed by the underlying simple ice flow model cannot account for the observed strong and rapid thinning below $\sim 60 \mathrm{~m}$ of depth (Fig. $7 \mathrm{~b}$ ). On the other hand, the Monte Carlo simulation is purely empirical, and does not require a glaciological model of unknown complexity. The resulting age-depth scale is exclusively defined by the reliability and precision of the individual dating horizons, and can account for potential changes in snow accumulation and/or strain rate (Fig. 11). It further allows for an objective uncertainty estimate for each depth, which is defined by the density of dating horizons and their individual uncertainties. As a consequence, the uncertainty is particularly high (20-50\%) between $58.67 \mathrm{~m}(1930 \mathrm{AD})$ and $68.96 \mathrm{~m}$ (1355 AD), where unfortunately no dating horizons exist (Fig. 11).
Future identification of additional dating horizons and counting of annual layers (e.g. using variations in stable isotopes, dust, pollen concentrations and/or species) could help to better constrain this model. However, additional ${ }^{210} \mathrm{~Pb}$ and ${ }^{14} \mathrm{C}$ techniques cannot be used because the age of the ice is either too high or too low for these methods. Horizons from volcanic fallout could not be identified so far in the upper and central part of the core, probably due to masking by the significant sulfate deposition from recent anthropogenic activities and the sedimentary background of Mt. Ortles.

\section{Discussion and implications}

\subsection{Age of the bottom ice}

Dating of the ice filtered from the Mt. Ortles cores with the ${ }^{14} \mathrm{C}$ method employing WIOC provides evidence for a bottom ice age of $6.7 \pm 0.4 \mathrm{kyrscal} B \mathrm{~B}$. The determination of ${ }^{14} \mathrm{C}$ in a larch leaf in core no. 1 by traditional methods provides an absolute and accurate timeline $(2.6 \pm 0.1 \mathrm{kyrs}$ cal BP) that is chronologically consistent with the ${ }^{14} \mathrm{C}$ ages of the ice samples (Fig. 11). While the exceptional thinning of the ice layer thicknesses below $58 \mathrm{~m}$ is difficult to explain, the monotonicity of the chronological empirical curve (Fig. 11) and of its derivative, together with the gradual change of the red index between $\sim 60$ and $\sim 70 \mathrm{~m}$ (Fig. 7), suggests that the thinning process operated consistently, at least at a millennial timescale. Thus, the overall ice core stratigraphy is likely continuous over millennia.

Nevertheless, a still unexplained physical process of thinning, or alternatively an unrecognized stratigraphic centennial-scale hiatus between 58 and $68 \mathrm{~m}$ of depth, must have taken place. Similar situations might also have been observed in other non-polar-latitude and high-altitude glaciers where the ice core records obtained were considered to be continuous (Thompson et al., 1995). We note that continuity 
Table 3. Data used in the depth-age modelling.

\begin{tabular}{|c|c|c|c|c|c|c|c|c|c|}
\hline $\begin{array}{l}\text { Time } \\
\text { reference }\end{array}$ & $\begin{array}{l}\text { Top depth } \\
\text { (m)* }\end{array}$ & $\begin{array}{l}\text { Bottom } \\
\text { depth }(\mathrm{m})^{*}\end{array}$ & $\begin{array}{l}\text { Mid depth } \\
(\mathrm{m})^{*}\end{array}$ & $\begin{array}{l}\text { Top depth } \\
\text { (m w.e.) })^{*}\end{array}$ & $\begin{array}{l}\text { Bottom depth } \\
\text { (m w.e.)* }\end{array}$ & $\begin{array}{l}\text { Mid depth } \\
(\mathrm{m} \text { w.e. })^{*}\end{array}$ & $\begin{array}{l}\text { Age } \\
\text { (yrs b2012) }\end{array}$ & $\begin{array}{l}\text { Age } \\
(\mathrm{AD}, \mathrm{BC})\end{array}$ & $\begin{array}{l}\sigma \\
\text { (years) }\end{array}$ \\
\hline Surface constrain & & & 0.00 & & & 0.00 & 0.3 & 2011.8 & 0 \\
\hline${ }^{210} \mathrm{~Pb}$ & & & 6.09 & & & 2.50 & 4.8 & 2007.2 & 0.4 \\
\hline${ }^{210} \mathrm{~Pb}$ & & & 10.39 & & & 5.00 & 9.3 & 2002.7 & 0.8 \\
\hline${ }^{210} \mathrm{~Pb}$ & & & 18.29 & & & 10.00 & 18.4 & 1993.6 & 1.6 \\
\hline${ }^{210} \mathrm{~Pb}$ & & & 25.25 & & & 15.00 & 27.5 & 1984.5 & 2.4 \\
\hline${ }^{210} \mathrm{~Pb}$ & & & 31.28 & & & 20.00 & 36.6 & 1975.4 & 3.2 \\
\hline Tritium peak & 40.58 & 41.27 & 40.92 & 29.71 & 30.34 & 30.02 & 49.0 & 1963 & 1 \\
\hline Beta emission peak & 43.33 & 44.04 & 43.69 & 32.23 & 32.88 & 32.56 & 54.0 & 1958 & 1 \\
\hline${ }^{210} \mathrm{~Pb}$ & & & 51.81 & & & 40.00 & 73.0 & 1939.0 & 6.5 \\
\hline${ }^{210} \mathrm{~Pb}$ & & & 57.26 & & & 45.00 & 82.1 & 1929.9 & 7.3 \\
\hline${ }^{14} \mathrm{C}$ in WIOC & 67.90 & 68.61 & 68.26 & 54.75 & 55.40 & 55.08 & 657 & 1355 & 205 \\
\hline${ }^{14} \mathrm{C}$ in WIOC & 71.15 & 71.60 & 71.38 & 57.73 & 58.15 & 57.94 & 1583 & 429 & 286 \\
\hline${ }^{14} \mathrm{C}$ in larch leaf & & & 73.19 & & & 59.60 & 2674 & -662 & 101 \\
\hline${ }^{14} \mathrm{C}$ in WIOC & 73.84 & 74.11 & 73.98 & 60.20 & 60.45 & 60.32 & 4235 & -2223 & 523 \\
\hline${ }^{14} \mathrm{C}$ in WIOC & 74.11 & 74.31 & 74.21 & 60.45 & 60.63 & 60.54 & 5240 & -3228 & 530 \\
\hline${ }^{14} \mathrm{C}$ in WIOC & 74.31 & 74.53 & 74.42 & 60.63 & 60.83 & 60.73 & 6804 & -4792 & 365 \\
\hline
\end{tabular}

* All depths referred to the Ortles core no. 2 depth scale.

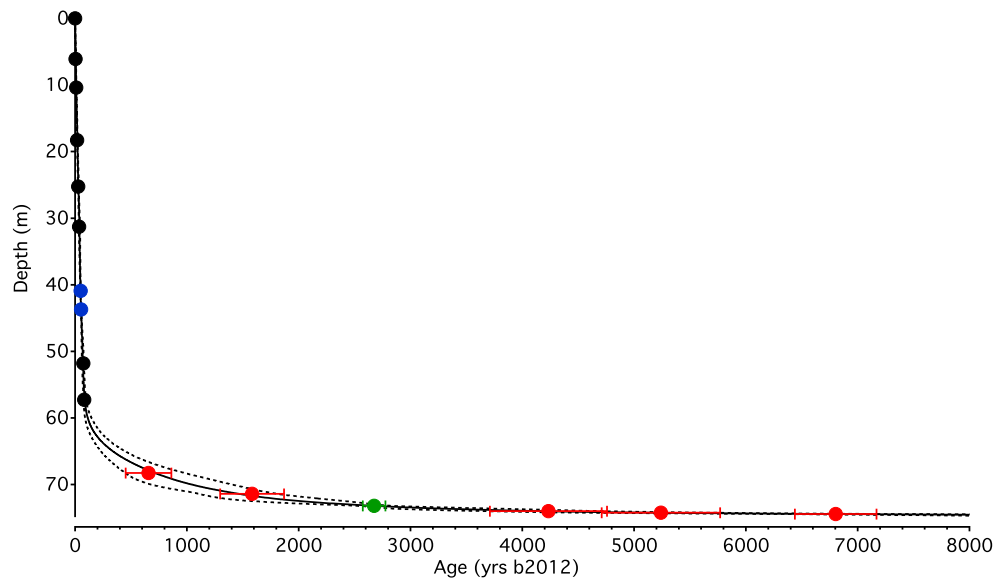

Figure 11. Construction of the Mt. Ortles ice core timescale. Age-depth relationship based on 2000 Monte Carlo realizations (continuous black line; dotted lines indicate the $1 \sigma$ confidence interval) fitting the absolute dated age horizons. Dots denote the surface and ${ }^{210} \mathrm{~Pb}$ ages (black); the tritium 1963 and beta 1958 peaks (blue); the calibrated ${ }^{14} \mathrm{C}$ WIOC ages (red) and the calibrated ${ }^{14} \mathrm{C}$ age of the larch leaf (green), all shown with their respective $1 \sigma$ uncertainty (data are presented in Table 3 ).

of the ice core records is relative to the timescale considered as, by their own nature, ice cores are constituted by wet deposition occurring intermittently at different timescales (e.g. meteorological (snow events), seasonal (wet-dry seasons), decadal (droughts caused by recurring patterns of oceanatmosphere climate variability etc.)), and thus stratigraphic hiatuses are the norm rather than the exception. However, despite the inherent hiatuses, when considering the appropriate timescale (millennial in our case), continuity of the ice core records can be assumed.

The preservation of early Holocene ice in the Alto dell'Ortles glacier is probably due to at least two factors. First, the location of the drill site in a rain shadow and its ex- posure to wind scour result in relatively low snow accumulation. The medium-term snow accumulation at the drilling site was estimated to be $850 \mathrm{~mm}$ w.e. $\mathrm{yr}^{-1}$ between 1963 and 2011. This latter value was obtained by applying the Nye model to correct for firn compaction and ice thinning down to the well-dated 1963 radioactive peak at $41 \mathrm{~m}$ of depth; this is consistent with the current 2011-2013 observations of $\sim 800 \mathrm{~mm}$ w.e. $\mathrm{yr}^{-1}$. Second, frozen bedrock (current value, $-2.8^{\circ} \mathrm{C}$ ) did not allow basal melting and a significant basal flow (see next section), thus preserving the oldest bottom ice in situ.

Last glacial age ice has been observed at several highaltitude-low-latitude drill sites such as Huascarán (Peru- 
vian Andes) (Thompson et al., 1995), Sajama and Illimani (Bolivian Andes) (Thompson et al., 1998; Ramirez et al., 2003) and Guliya (Western Tibetan Plateau) (Thompson et al., 1997). In contrast, ice core records from the western Alps typically extend over just a few centuries (Barbante et al., 2004; Preunkert et al., 2001; Schwikowski et al., 1999a; Van de Velde et al., 2000b). However, the ice embedded in the deepest layers of Alto dell'Ortles dates to the demise of the Northern Hemisphere Climate Optimum (NHCO), and is among the oldest ice discovered in the European Alps, exceeded in age only by the ice more than 10 kyrs old retrieved at Colle Gnifetti (Jenk et al., 2009). We surmise that Last Glacial Maximum ice does not exist in the Mt. Ortles record because of the lack of the stable isotopic depletion (4 to 5\%o) characteristic of such ice in the bottom of Alto dell'Ortles (Fig. 10). Bottom ice from several other low-latitude-highaltitude drill sites such as Dasuopu (Himalaya) (Thompson et al., 2000) and Tsambagarav (Western Mongolia) (Herren et al., 2013) behaves in the same way, and extends back several millennia to the mid-Holocene.

\subsection{Dynamic of the bottom ice}

When considering the location of the drill site in the uppermost part of the glacier Alto dell'Ortles, the current glacier flow ( $3.2 \mathrm{~m} \mathrm{yr}^{-1}$ at the surface, $\geq 0 \mathrm{~m} \mathrm{yr}^{-1}$ at the base) and the age of the Mt. Ortles ice cores $(6.7 \mathrm{kyrs}$ cal BP at the bottom), one may wonder why such old ice deposited on the summit of Alto dell'Ortles was not quickly removed during the Holocene. Here we demonstrate that the only possible answer is that the observed significant ice flow must be a very recent phenomenon, and that consequently a much slower basal flow has typically been common since the NHCO.

To study the origin of the Mt. Ortles bottom ice quantitatively, and to verify its consistency with the local geography (e.g. the core layers cannot originate from a location beyond the margins of the glacier), we have employed a simple bi-dimensional dynamic model that estimates the lower limit of the distance covered by a single glacier layer over time, under the null hypothesis of an unchanged past dynamic of the glacier from the current conditions. We have therefore assumed a linear variation of the glacier velocity with depth $\left(V_{x}\right)$ (as determined by means of current inclinometric measurements) between a negligible value $\left(0 \mathrm{~m} \mathrm{yr}^{-1}\right.$ at the bedrock, current lower limit value) and $2.6 \mathrm{~m} \mathrm{yr}^{-1}$ (current lower value recorded at the surface by GPS). For modelling the vertical glacier flow $\left(V_{z}\right)$ we have employed two approaches: (i) conservative use of a Nye model (not shown), and (ii) more realistically, a linear combination of exponential functions that interpolate the empirical chronological timelines obtained along the depth profile (Fig. 12).

The results are generally consistent with our ice core sections originating uphill from the drill site along the flow line (Fig. 3). For instance, the 1963 radioactive ice layer (at $41 \mathrm{~m}$ ) would originate from a location that is at least $90 \mathrm{~m}$ uphill of the drill site (using both the conservative and realistic $V_{z}$ ). However, several thousand-year-old ice (below $70 \mathrm{~m}$ of depth) would originate from an unrealistic minimum distance that is $300-500 \mathrm{~m}$ uphill (using the conservative and realistic $V_{z}$, respectively), thus much larger than the distance between the drill site and the origin of the flow lines (Fig. 3). As this result contradicts the null hypothesis of unchanged dynamic conditions over time, we conclude that the formation and preservation of very old ice at the Alto dell'Ortles drill site was possible, only when the flow velocity of the ice layers near the base was much lower throughout the time since the formation, when compared to the values measured today. In other words, the significantly positive glacier flow $V_{x}$ near the base, which was recorded in the present day, must be the result of a very recent change in the ice dynamics at the drill site.

We interpret this result as being possibly indicative of a large-scale dynamic change, probably involving the entire Alto dell'Ortles. However, this dynamic variation is likely not caused by changes in the slope of this glacier that, according to our large-scale comparisons of the DTMs employed (not shown), seem negligible, even under the action of the strong ablation occurring since 1980, especially in terms of calving at the lowermost margins of Alto dell'Ortles. Instead, we speculate that this dynamic variation may be a consequence of two possible alternatives or concomitant factors: (i) recent summer meltwater influx from the bed outcrops uphill from the basal portion of the drilling site may be lubricating the glacier/bedrock interface. As shown for coldbased ice caps and ice sheets in Svalbard and Greenland, there is evidence that seasonal meltwater can reach bedrock and change the ice velocity (Bartholomew et al., 2010; Dunse et al., 2015). This would be consistent with the observed seasonal changes in the surface velocity, and with the quasilinear profile of $V_{x}$ obtained with the inclinometer (Fig. 4). (ii) Changes in the plastic behaviour of the cold portion of the glacier as a consequence of the ongoing thermic transition from polythermal to temperate conditions may play a role. This latter hypothesis would be consistent with (a) a negligible basal flow, (b) long-term changes in the vertical thermal profile (perhaps particularly significant since the end of the LIA) and (c) the observed significant elevation changes of the drilling site during the last century.

\subsection{The Alto dell'Ortles glaciation during the Holocene}

A marked stable isotopic enrichment observed in the speleothem record from Spannagel Cave (2500 m, Austria) during the NHCO (Vollweiler et al., 2006) suggests that this period was likely the warmest during the entire Holocene in the sector of the Alps where Alto dell'Ortles is located. This is consistent with the minimum thickness of the Upper Grindelwald Glacier in Switzerland between 9.2 and $6.8 \mathrm{kyrs}$ BP (Luetscher et al., 2011) and with the minimum extent of the Tschierva Glacier in the adjacent Mt. Bernina 


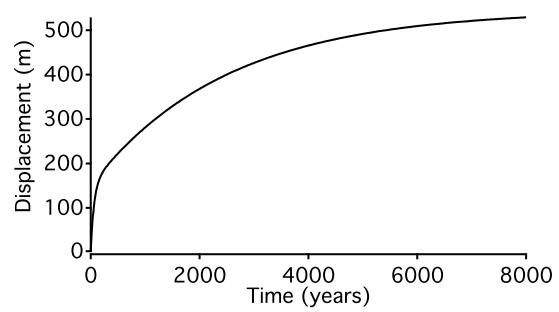

Figure 12. Horizontal displacement of a hypothetical glacier layer sinking from the surface to bedrock according to the vertical dynamic that follows the empirical age-depth relationship developed in this work.

group (Joerin et al., 2008), which indicates that the equilibrium line altitude (ELA) was $220 \pm 20 \mathrm{~m}$ higher than the 1985 reference level $(2820 \mathrm{~m})$.

Today the estimated ELA on Alto dell'Ortles lies at about $3300 \mathrm{~m}$ as inferred from in situ observations and from the ELA obtained from the nearby glacier of Vedretta della Mare (Carturan, 2016). Under the current warm climatic conditions the drilling site $(3859 \mathrm{~m})$ is polythermal, characterized by temperate firn and cold basal ice. Similarly to the adjacent Mt. Bernina group, the ELA was almost certainly higher than today on Alto dell'Ortles during the NHCO, and thus it is certainly possible that this glacier was entirely under a temperate regime throughout its thickness. This would imply the occurrence of basal melting/sliding and thinning of the glacier and the quick removal of bottom ice during the NHCO. This mechanism might explain the absence of ice older than 6.7 kyrs BP at the drill site. Remarkably, a chironomid-based air temperature reconstruction from another nearby site from Schwarzsee ob Sölden ( $2796 \mathrm{~m}$, Austria) suggests that it was $\sim 2{ }^{\circ} \mathrm{C}$ warmer than today during the $7.9-4.5 \mathrm{kyr} \mathrm{BP}$ period (Ilyashuk et al., 2011). This finding, when combined with recent field evidence, supports the hypothesis of temperate conditions during the NHCO, and indicates the possibility of a complete deglaciation of the drilling site during the warmest phase of the NHCO.

At the end of the NHCO temperatures started to decrease (Vollweiler et al., 2006), probably causing a reversal of the thermal regime of Alto dell'Ortles from temperate to polythermal, and thus allowing the accumulation of cold ice on frozen bedrock. As inferred from European palaeolake levels, a short increase in precipitation at $\sim 7$ kyrs BP (Magny, 2004) could also have contributed higher accumulation and ice thickening recorded/inferred at $\sim 6.8 \mathrm{kyrs} \mathrm{BP}$ for small and climatically sensitive glaciers such as Upper Grindelwald (Luetscher et al., 2011) and Alto dell'Ortles (this work). Although high precipitation did not persist during the midHolocene, progressively more favourable glacial conditions characterized the eastern Alps at the end of the NHCO. While there was at least a warm spell (4.4-4.2 kyrs BP) in this area (Baroni and Orombelli, 1996), glaciers extended in general to lower elevations, including the Tisenjoch (3210 m) where the Tyrolean Iceman was buried in snow and ice since $5.3 \mathrm{kyrs}$ BP. Today, due to strong atmospheric summer warming, Alto dell'Ortles is transitioning back from a polythermal to a temperate state. Basal sliding conditions that could have occurred only during the NHCO are likely to be soon, or are already, fully restored, with important and immediate consequences for the dynamic of the entire glacier.

\section{Conclusions}

\subsection{Palaeoclimatological conclusions}

- The glacier Alto dell'Ortles contains a $\sim 75 \mathrm{~m}$ record that spans $\sim 7$ kyrs of climatic and environmental history in the Alps. Dating back to the demise of the Northern Hemisphere Climatic Optimum, Mt. Ortles ice is among the oldest discovered in the European Alps.

- The Mt. Ortles drilling site was continuously glaciated on frozen bedrock since $\sim 7 \mathrm{kyrs}$ BP. Absence of older ice is consistent with removal of basal ice from bedrock during the Northern Hemisphere Climatic Optimum.

\subsection{Glaciological conclusions}

- The 2011 Fukushima radioactive signal was embedded in the shallow 2011 snow layers of the Mt. Ortles cores. This result further suggests that this event may be a new glaciological time horizon at a hemispheric scale, although only in the short term, due to the short half-life of the radionuclides likely involved such as ${ }^{131} \mathrm{I}$.

- During the last century the Mt. Ortles drilling site experienced significant elevation changes (with a net lowering on the order of $\sim 10 \mathrm{~m}$ ).

- From 1963 to 2011 the accumulation rate at the drilling site $\left(850 \mathrm{~mm} \mathrm{yr}^{-1}\right)$ is comparable to the rate $\left(\sim 800 \mathrm{~mm} \mathrm{yr}^{-1}\right)$ measured during the last few warm years (2011-2013).

- Dating of the upper core layers (mainly performed by means of ${ }^{210} \mathrm{~Pb}$ ) and bottom layers (performed by means of ${ }^{14} \mathrm{C}$ ) could only be empirically, but not physically, reconciled. While the Mt. Ortles ice core record can be considered continuous at a millennial timescale, a centennial hiatus in the stratigraphy between $58.67 \mathrm{~m}$ (1930 AD) and $68.96 \mathrm{~m}$ (1355 AD) cannot be entirely ruled out.

- Even assuming negligible basal sliding, detection of a significant shift of the deep ice layers relative to basal ice suggests a recent flow acceleration of the upper portion of Alto dell'Ortles that is unprecedented over the past $\sim 7 \mathrm{kyrs}$. Thus, we can expect that the old basal ice will be removed long before any possible deglaciation of Mt. Ortles in the future. 


\section{Data availability}

The data presented in this work are archived at the National Oceanic and Atmospheric Administration World Data Center-A for Palaeoclimatology: https://www.ncdc. noaa.gov/paleo/study/20367.

Acknowledgements. This work is a contribution to the Ortles project, a programme supported by two NSF awards no. 1060115 \& no. 1461422 to The Ohio State University and by the Ripartizione Protezione antincendi e civile of the autonomous province of Bolzano in collaboration with the Ripartizione Opere idrauliche e Ripartizione Foreste of the autonomous province of Bolzano and the Stelvio National Park. This is Ortles project publication 7 (www.ortles.org) and Byrd Polar and Climate Research Center contribution 1555. The authors are grateful to the Alpine guides of the Alpinschule of Solda, the Institute of Mountain Emergency Medicine of EURAC, the helicopter companies Airway, Air Service Center, Star Work Sky and the Hotel Franzenshöhe for the logistical support. We are also grateful for the valuable contribution of Lonnie Thompson in planning/performing the logistic activity and discussing the ice core data. Finally, we would like to thank Sebastian Luening, Michael Kuhn and an anonymous reviewer for valuable comments, which allowed us to improve this manuscript, and Matteo Cocetti for his help in the mathematical development of the model.

Edited by: M. van den Broeke

Reviewed by: M. Kuhn and one anonymous referee

\section{References}

Auer, I., Bohm, R., Jurkovic, A., Lipa, W., Orlik, A., Potzmann, R., Schoner, W., Ungersbock, M., Matulla, C., Briffa, K., Jones, P., Efthymiadas, D., Brunetti, M., Nanni, T., Maugeri, M., Mercalli, L., Mestre, O., Moisselin, J.-M., Begert, M., MullerWestermeier, G., Kveton, V., Bochnicek, O., Stastny, P., Lapin, M., Szalai, S., Szentimrey, T., Cegnar, T., Dolinar, M., GaljicCapka, M., Zaninovic, K., Majstorovic, Z., and Nieplova, E.: HISTALP - historical instrumental climatological surface time series of the Greater Alpine Region, Int. J. Climate, 27, 17-46, 2006.

Barbante, C., Van de Velde, K., Cozzi, G., Capodaglio, G., Cescon, P., Planchon, F., Hong, S., Ferrari, C., and Boutron, C. F.: PostWorld War II uranium changes in dated Mont Blanc ice and snow, Environ. Sci. Technol., 35, 4026-4030, doi:10.1021/es0109186, 2001.

Barbante, C., Schwikowski, M., Doring, T., Gäggeler, H. W., Shottered, U., Tobler, L., Van de Velde, K., Ferrari, C., Cozzi, G., Turetta, A., Rosman, K., Bolshov, M. A., Capodaglio, G., Cescon, P., and Boutron, C. F.: Historical record of European emission of heavy metals to the atmosphere since the 1650s from alpine snow/ice cores drilled near Monte Rosa, Environ. Sci. Technol., 38, 4085-4090, doi:10.1021/es049759r, 2004.

Baroni, C. and Orombelli, G.: The Alpine "Iceman" and Holocene climatic change, Quat. Res., 46, 78-83, 1996.
Bartholomew, I., Nienow, P., Mair, D., Hubbard, A., King, M. A., and Sole, A.: Seasonal evolution of subglacial drainage and acceleration in a Greenland outlet glacier, Nat. Geosci., 3, 408-411, 2010.

Berger, A. and Loutre, M. F.: Insolation values for the climate of the last 10 million years, Quaternary Sci. Rev., 10, 297-317, doi:10.1016/0277-3791(91)90033-Q, 1991.

Binder, D., Brueckl, E., Roch, K. H., Behm, M., Schoener, W., and Hynek, B.: Determination of total ice volume and ice-thickness distribution of two glaciers in the Hohe Tauern region, Eastern Alps, from GPR data, Ann. Glaciol., 50, 71-79, 2009.

Blindow, N. and Thyssen, F.: Ice thickness and inner structure of the Vernagtferner (Oetztal Alps): results of electromagnetic reflection measurements, Z. Gletscherkd. Glazialgeol., 22, 43-60, 1986.

Bortenschlager, S., Kofler, W., Oeggl, K., and Schoch, W.: Erste Ergebnisse der Auswertung der vegetabilischen Reste vom Hauslabjochfund, Der Mann im Eis, Universität Innsbruck, Innsbruck, 307-312, 1992.

Breitenbach, S. F. M., Rehfeld, K., Goswami, B., Baldini, J. U. L., Ridley, H. E., Kennett, D. J., Prufer, K. M., Aquino, V. V., Asmerom, Y., Polyak, V. J., Cheng, H., Kurths, J., and Marwan, N.: COnstructing Proxy Records from Age models (COPRA), Clim. Past, 8, 1765-1779, doi:10.5194/cp-8-1765-2012, 2012.

Bronk Ramsey, C. and Lee, S.: Recent and planned developments of the Program OxCal, Radiocarbon, 55, 720-730, 2013.

Carturan, L.: Replacing monitored glaciers undergoing extinction: a new measurement series on La Mare Glacier (Ortles-Cevedale, Italy), J. Glaciol., doi:10.1017/jog.2016.107, 2016.

Carturan, L., Filippi, R., Seppi, R., Gabrielli, P., Notarnicola, C., Bertoldi, L., Paul, F., Rastner, P., Cazorzi, F., Dinale, R., and Dalla Fontana, G.: Area and volume loss of the glaciers in the Ortles-Cevedale group (Eastern Italian Alps): controls and imbalance of the remaining glaciers, The Cryosphere, 7, 13391359, doi:10.5194/tc-7-1339-2013, 2013.

Clemenza, M., Fiorini, E., Previtali, E., and Sala, E.: Measurement of airborne ${ }^{131} \mathrm{I},{ }^{134} \mathrm{Cs}$ and ${ }^{137} \mathrm{Cs}$ due to the Fukushima reactor incident in Milan (Italy), J. Environ. Radioactiv., 114, 113-118, doi:10.1016/j.jenvrad.2011.12.012, 2012.

Dunse, T., Schellenberger, T., Hagen, J. O., Kääb, A., Schuler, T. V., and Reijmer, C. H.: Glacier-surge mechanisms promoted by a hydro-thermodynamic feedback to summer melt, The Cryosphere, 9, 197-215, doi:10.5194/tc-9-197-2015, 2015.

Eichler, A., Schwikowski, M., Gaeggeler, H. W., Furrer, V., Synal, H. A., Beer, J., Saurer, M., and Funk, M.: Glaciochemical dating of an ice core from upper Grenzgletscher (4200 m a.s.1.), J. Glaciol., 46, 507-515, 2000.

Eichler, A., Schwikowski, M., and Gäggeler, H. W.: Meltwaterinduced relocation of chemical species in Alpine firn, Tellus B, 53B, 192-203, 2001.

Ezerinskis, Z., Spolaor, A., Kirchgeorg, T., Cozzi, G., Vallelonga, P., Kjaer, H. A., Sapolaite, J., Barbante, C., and Druteikiene, R.: Determination of ${ }^{129} \mathrm{I}$ in Arctic snow by a novel analytical approach using IC-ICP-SFMS, J. Anal. Atom. Spectrom., 29, 1827-1834, doi:10.1039/c4ja00179f, 2014.

Festi, D., Kofler, W., Bucher, E., Mair, V., Gabrielli, P., Carturan, L., and Oeggl, K.: A novel pollen-based method to detect seasonality in ice cores: a case study from the Ortles Glacier (South Tyrol, Italy), J. Glaciol., 61, 815-824, 2015. 
Gabrieli, J., Cozzi, G., Vallelonga, P., Schwikowski, M., Sigl, M., Eickenberg, J., Wacker, L., Boutron, C., Gäggeler, H., Cescon, P., and Barbante, C.: Contamination of Alpine snow and ice at Colle Gnifetti, Swiss/Italian Alps, from nuclear weapons tests, Atmos. Environ., 45, 587-593, doi:10.1016/j.atmosenv.2010.10.039, 2011.

Gabrielli, P., Carturan, L., Gabrieli, J., Dinale, R., Krainer, K., Hausmann, H., Davis, M., Zagorodnov, V. S., Seppi, R., Barbante, C., Dalla Fontana, G., and Thompson, L. G.: Atmospheric warming threatens the untapped glacial archive of Ortles mountain, South Tyrol, J. Glaciol., 56, 843-853, doi:10.4461/GFDQ.2012.35.10, 2010.

Gabrielli, P., Barbante, C., Carturan, L., Cozzi, G., Dalla Fontana, G., Dinale, R., Draga, G., Gabrieli, J., Kehrwald, N., Mair, V., Mikhalenko, V. N., Piffer, G., Rinaldi, M., Seppi, R., Spolaor, A., Thompson, L. G., and Tonidandel, D.: Discovery of cold ice in a new drilling site in the Eastern European Alps, Geogr. Fis. Dinam. Quat., 35, 101-105, 2012.

Gäggeler, H., Gunten, H. R. V., Rössler, E., Oeschger, H., and Schotterer, U.: ${ }^{210} \mathrm{~Pb}$-dating of cold Alpine firn/ice cores from Colle Gnifetti, Switzerland, J. Glaciol., 29, 165-177, 1983.

Galos, S., Klug, C., Prinz, R., Rieg, R., Saller, R., Dinale, R., and Kaser, G.: Recent glacier changes and related contribution potential to river discharge in the Vinschgau / Val Venosta, Italian Alps, Geogr. Fis. Dinam. Quat., 38, 143-154, doi:10.4461/GFDQ.2015.38.13, 2015.

Golubev, G. N.: The water regime of the glaciological zones, Snow and Ice-Symposium - Neiges et glaces, Proceedings of the Moscow Symposium, August 1971, Moscow, 1975, 111-122, 1975.

Haeberli, W. and Alean, J.: Temperature and accumulation of high altitude firn in the Alps, Ann. Glaciol., 6, 161-163, 1985.

Herren, P.-A., Eichler, A., Machguth, H., Papina, T., Tobler, L., Zapf, A., and Schwikowski, M.: The onset of neoglaciation 6000 years ago in western Mongolia revealed by an ice core from the Tsambagarav mountain range, Quat. Sci. Rev., 69, 59-68, doi:10.1016/j.quascirev.2013.02.025, 2013.

Holzhauser, H.: Fluctuations of the Grosser Aletsch Glacier and the Gorner Glacier during the last 3200 years: New results, in: Glacier Fluctuations During the Holocene, edited by: Frenzel, B., Boulton, G. S., Glaser, B., and Huckriede, U., Gustav Fischer Verlag, Stuttgart, Jena, Lübeck, Ulm, 35-58, 1997.

Holzhauser, H., Magny, M., and Zumbühl, H. J.: Glacier and lakelevel variations in west-central Europe over the last 3500 years, The Holocene, 15, 789-801, 2005.

Hormes, A., Müller, B. U., and Schlüchter, C.: The Alps with little ice: evidence for eight Holocene phases of reduced glacier extent in the Central Swiss Alps, The Holocene, 11, 255-265, 2001.

Ilyashuk, E. A., Koinig, K. A., Heiri, O., Ilyashuk, B. P., and Psenner, R.: Holocene temperature variations at a highaltitude site in the Eastern Alps: a chironomid record from Schwarzsee ob Sölden, Austria, Quat. Sci. Rev., 30, 176-191, doi:10.1016/j.quascirev.2010.10.008, 2011.

Ivy-Ochs, S., Kerschner, H., Reuther, A., Preusser, F., Heine, K., Maisch, M., Kubik, P. W., and Schlüchter, C.: Chronology of the last glacial cycle in the European Alps, J. Quat. Sci., 23, 559573, doi:10.1002/jqs.1202, 2008.

Ivy-Ochs, S., Kerschner, H., Maisch, M., Christl, M., Kubik, P. W., and Schlüchter, C.: Latest Pleistocene and Holocene glacier vari- ations in the European Alps, Quat. Sci. Rev., 28, 2137-2149, doi:10.1016/j.quascirev.2009.03.009, 2009.

Jenk, T. M., Szidat, S., Schwikowski, M., Gäggeler, H. W., Brütsch, S., Wacker, L., Synal, H. A., and Saurer, M.: Radiocarbon analysis in an Alpine ice core: record of anthropogenic and biogenic contributions to carbonaceous aerosols in the past (1650-1940), Atmos. Chem. Phys., 6, 5381-5390, doi:10.5194/acp-6-53812006, 2006.

Jenk, T. M., Szidat, S., Schwikowski, M., Gäggeler, H. W., Wacker, L., Synal, H. A., and Saurer, M.: Microgram level radiocarbon $\left({ }^{14} \mathrm{C}\right)$ determination on carbonaceous particles in ice, Nucl. Instrum. Meth. B, 259, 518-525, doi:10.1016/j.nimb.2007.01.196, 2007.

Jenk, T. M., Szidat, S., Bolius, D., Sigl, M., Gäggeler, H. W., Wacker, L., Ruff, M., Barbante, C., Boutron, C. F., and Schwikowski, M.: A novel radiocarbon dating technique applied to an ice core from the Alps indicating late Pleistocene ages J. Geophys. Res.-Atmos., 114, D14305, doi:10.1029/2009JD011860, 2009.

Joerin, U. E., Stocker, T. F., and Schlüchter, C.: Multicentury glacier fluctuations in the Swiss Alps during the Holocene, The Holocene, 16, 697-704, 2006.

Joerin, U. E., Nicolussi, K., Fischer, A., Stocker, T. F., and Schlüchter, C.: Holocene optimum events inferred from subglacial sediments at Tschierva Glacier, Eastern Swiss Alps, Quat Sci. Rev., 27, 337-350, doi:10.1016/j.quascirev.2007.10.016, 2008.

Konrad, H., Bohleber, P., Wagenbach, D., Vincent, C., and Eisen, O.: Determining the age distribution of Colle Gnifetti, Monte Rosa, Swiss Alps, by combining ice cores, ground-penetrating radar and a simple flow model, J. Glaciol., 59, 177-189, doi:10.3189/2013JoG12J072, 2013.

Kovacs, A., Gow, A. J., and Morey, R. M.: The in-situ dielectric constant of polar firn revisited, Cold Reg. Sci. Technol., 23, 245256, 1995.

Larocque-Tobler, I., Grosjean, M., Heiri, O., Trachsel, M., and Kamenik, C.: Thousand years of climate change reconstructed from chironomid subfossils preserved in varved lake Silvaplana, Engadine, Switzerland, Quat. Sci. Rev., 29, 1940-1949, doi:10.1016/j.quascirev.2010.04.018, 2010.

Legrand, M., Preunkert, S., Wagenbach, D., Cachier, H., and Puxbaum, H.: A historical record of formate and acetate from a high elevation Alpine glacier: Implications for their natural versus anthropogenic budgets at the European scale, J. Geophys Res.-Atmos., 108, 4788, doi:10.1029/2003JD003594, 2003.

Lin, W., Chen, L., Yu, W., Ma, H., Zeng, Z., Lin, J., and Zeng, S.: Radioactivity impacts of the Fukushima Nuclear Accident on the atmosphere, Atmos. Environ., 102, 311-322, doi:10.1016/j.atmosenv.2014.11.047, 2015.

Loaiza, P., Chassaing, C., Hubert, P., Nachab, A., Perrot, F., Reyss, J. L., and Warot, G.: Low background germanium planar detector for gamma-ray spectrometry, Nucl. Instrum. Meth. A, 634, 64 70, doi:10.1016/j.nima.2011.01.017, 2011.

Luetscher, M., Hoffmann, D. L., Frisia, S., and Spötl, C.: Holocene glacier history from alpine speleothems, Milchbach cave, Switzerland, Earth Planet. Sc. Lett., 302, 95-106, doi:10.1016/j.epsl.2010.11.042, 2011.

Magand, O.: Bilan de masse de surface Antarctique : Techniques de mesure et analyse critiques, thèse de doctorat de l'Université 
Joseph Fourier, Grenoble 1, 355 pp., Université Joseph Fourier, Grenoble, 2009.

Maggi, V., Orombelli, G., Stenni, B., Flora, O., Udisti, R., Becagli, S., Traversi, R., Vermigli, S., and Petit, J. R.: 70 years of northern Victoria Land (Antarctica) accumulation rate, Ann. Glaciol., 27, 215-219, 1998

Magny, M.: Holocene climate variability as reflected by midEuropean lake-level fluctuations and its probable impact on prehistoric human settlements, Quatern. Int., 113, 65-79, doi:10.1016/S1040-6182(03)00080-6, 2004.

Magny, M. and Haas, J. N.: A major widespread climatic change around 5300 cal. yr BP at the time of the Alpine Iceman, J. Quat. Sci., 19, 423-430, 2004.

Masson, O., Baeza, A., Bieringer, J., Brudecki, K., Bucci, S., Cappai, M., Carvalho, F. P., Connan, O., Cosma, C., Dalheimer, A., Didier, D., Depuydt, G., De Geer, L. E., De Vismes, A., Gini, L., Groppi, F., Gudnason, K., Gurriaran, R., Hainz, D., Halldórsson, Ó., Hammond, D., Hanley, O., Holeý, K., Homoki, Z., Ioannidou, A., Isajenko, K., Jankovic, M., Katzlberger, C., Kettunen, M., Kierepko, R., Kontro, R., Kwakman, P. J. M., Lecomte, M., Leon Vintro, L., Leppänen, A. P., Lind, B., Lujaniene, G., Mc Ginnity, P., McMahon, C., Malá, H., Manenti, S., Manolopoulou, M., Mattila, A., Mauring, A., Mietelski, J. W., Møller, B., Nielsen, S. P., Nikolic, J., Overwater, R. M. W., Pálsson, S. E., Papastefanou, C., Penev, I., Pham, M. K., Povinec, P. P., Ramebäck, H., Reis, M. C., Ringer, W., Rodriguez, A., Rulík, P., Saey, P. R. J., Samsonov, V., Schlosser, C., Sgorbati, G., Silobritiene, B. V., Söderström, C., Sogni, R., Solier, L., Sonck, M., Steinhauser, G., Steinkopff, T., Steinmann, P., Stoulos, S., Sýkora, I., Todorovic, D., Tooloutalaie, N., Tositti, L., Tschiersch, J., Ugron, A., Vagena, E., Vargas, A., Wershofen, H., and Zhukova, O.: Tracking of airborne radionuclides from the damaged Fukushima Dai-Ichi nuclear reactors by European networks, Environ. Sci. Technol., 45, 7670-7677, doi:10.1021/es2017158, 2011.

Mietelski, J. W., Kierepko, R., Brudecki, K., Janowski, P., Kleszcz, K., and Tomankiewicz, E.: Long-range transport of gaseous ${ }^{131} \mathrm{I}$ and other radionuclides from Fukushima accident to Southern Poland, Atmos. Environ., 91, 137-145, doi:10.1016/j.atmosenv.2014.03.065, 2014.

Moran, M. L., Greenfield, R. J., Arcone, S. A., and Delaney, A. J.: Delineation of a complexly dipping temperate glacier bed using short-pulse radar arrays, J. Glaciol., 46, 274-286, 2000.

Nicolussi, K. and Patzelt, G.: Discovery of early Holocene wood and peat on the forefield of the Pasterze Glacier, Eastern Alps, Austria, The Holocene, 10, 191-199, 2000.

Oerlemans, J.: Glaciers and climate change, A. A. Balkema publishers, Lisse, Netherlands, Exton PA, Tokyo, 148 pp., 2001.

Oerter, H., Baker, D., Stichler, W., and Rauert, W.: Isotope studies of ice cores froma a temperate Alpine glacier (Vernagtferner, Austria) with respect to the meltwater flow, Ann. Glaciol., 7, 90-93, 1985.

Paterson, W. S. B.: The physics of glaciers, 3 ed., edited by: Paperback, Butterworth Heinemann, Oxford, 481 pp., 1999.

Porter, S. C. and Orombelli, G.: Glacier contraction during the middle Holocene in the western Italian Alps: Evidence and implications, Geology, 13, 296-298, 1985.

Pourchet, M., Magand, O., Frezzotti, M., Ekaykin, A., and Winther, J. G.: Radionuclides deposition over Antarctica, J. Environ.
Radioactiv., 68, 137-158, doi:10.1016/S0265-931x(03)00055-9, 2003.

Povinec, P. P., Gera, M., Holý, K., Hirose, K., Lujaniené, G., Nakano, M., Plastino, W., Sýkora, I., Bartok, J., and Gažák, M.: Dispersion of Fukushima radionuclides in the global atmosphere and the ocean, Appl. Radiat. Isotopes, 81, 383-392, doi:10.1016/j.apradiso.2013.03.058, 2013.

Preunkert, S., Wagenbach, D., Legrand, M., and Vincent, C.: Col du Dome (Mt. Blanc Massif, French Alps) suitability for ice-core studies in relation with past atmospheric chemistry over Europe, Tellus B, 52B, 993-1012, 2000.

Preunkert, S., Legrand, M., and Wagenbach, D.: Sulfate trends in a Col du Dome (French Alps) ice core: A record of anthropogenic sulfate levels in the European midtroposphere over the twentieth century, J. Geophys. Res.-Atmos., 106, 31991-32004, doi:10.1029/2001JD000792, 2001.

Ramirez, E., Hoffmann, G., Taupin, J. D., Francou, B., Ribstein, P., Caillon, N., Ferron, F. A., Landais, A., Petit, J. R., Pouyaud, B., Schotterer, U., Simoes, J. C., and Stievenard, M.: A new Andean deep ice core from Nevado Illimani $(6350 \mathrm{~m})$, Bolivia, Earth Planet. Sc. Lett., 212, 337-350, doi:10.1016/S0012821X(03)00240-1, 2003.

Ravazzi, C., Pini, R., Badino, F., De Amicis, M., Londeix, L., and Reimer, P. J.: The latest LGM culmination of the Garda Glacier (Italian Alps) and the onset of glacial termination. Age of glacial collapse and vegetation chronosequence, Quat. Sci. Rev., 105, 26-47, doi:10.1016/j.quascirev.2014.09.014, 2014.

Reimer, P. J., Bard, E., Bayliss, A., Beck, J. W., Blackwell, P. G., Bronk Ramsey, C., Buck, C. E., Cheng, H., Edwards, R. L., Friedrich, M., Grootes, P. M., Guilderson, T. P., Haflidason, H., Hajdas, I., Hatté, C., Heaton, T. J., Hoffmann, D. L., Hogg, A. G., Hughen, K. A., Kaiser, K. F., Kromer, B., Manning, S. W., Niu, M., Reimer, R. W., Richards, D. A., Scott, E. M., Southon, J. R., Staff, R. A., Turney, C. S. M., and van der Plicht, J.: IntCal13 and Marine13 radiocarbon age calibration curves 0-50,000 years cal BP, Radiocarbon, 55, 1869-1887, 2013.

Schotterer, U., Schwartz, P., and Rajner, V.: From pre-bomb levels to industrial times: A complete tritium record from an alpine ice core and its relevance for environmental studies, International Atomic Energy Agency, 581-590, 1998.

Schwarb, M.: The alpine precipitation climate. Evaluation of a highresolution analysis scheme using comprehensive rain-gauge data, $\mathrm{PhD}$, Swiss Federal Institute of Technology Zurich, Zurich, 131 pp., 2000.

Schwikowski, M., Brutsch, S., Gaeggeler, H. W., and Shotterer, U.: A high-resolution air chemistry record from an Alpine ice core: Fiescherhorn glacier, Swiss Alps, J. Geophys. Res.-Atmos., 104, 13709-13719, doi:10.1029/1998JD100112, 1999a.

Schwikowski, M., Doscher, A., Gäggeler, H. W., and Schotterer, U.: Anthropogenic versus natural sources of atmospheric sulphate from an Alpine ice core, Tellus B, 51, 938-951, 1999b.

Seidler, H., Bernhard, W., Teschler-Nicola, M., Platzer, W., zur Nedden, D., Henn, R., Oberhauser, A., and Sjovold, T.: Some anthropological aspects of the prehistoric Tyrolean ice man, Science, 258, 455-457, 1992.

Sigl, M., Jenk, T. M., Kellerhals, T., Szidat, S., Gäggeler, H. W., Wacker, L., Synal, H. A., Boutron, C. F., Barbante, C., Gabrieli, J., and Schwikowski, M.: Intruments and methods: towards radiocarbon dating of ice cores, J. Glaciol., 55, 985-996, 2009. 
Stuiver, M., Reimer, P. J., and Braziunas, T. F.: High-precision radiocarbon age calibration for terrestrial and marine samples, Radiocarbon, 40, 1127-1151, 1998.

Suter, S., Laternser, M., Haeberly, W., Frauenfelder, R., and Hoelzle, M.: Cold firn and ice of high-altitude glaciers in the Alps: measurements and distribution modelling, J. Glaciol., 47, 85-96, 2001.

Thompson, L. G., Mosley-Thompson, E., Davis, M. E., Lin, P.-N., Henderson, K. A., Cole-Dai, J., Bolzan, J. F., and Liu, K.-B.: Late Glacial Stage and Holocene tropical ice core records from Huascarán, Peru, Science, 269, 46-50, doi:10.1126/science.269.5220.46, 1995.

Thompson, L. G., Yao, T., Davis, M., Henderson, K. A., MosleyThompson, E., Lin, P. N., Beer, J., Synal, H. A., Cole-Dai, J., and Bolzan, J. F.: Tropical climate instability: the last glacial cycle from a Qinghai-Tibetan ice core, Science, 276, 1821-1827, doi:10.1126/science.276.5320.1821, 1997.

Thompson, L. G., Davis, M. E., Mosley-Thompson, E., Sowers, T., Henderson, K. A., Zagorodnov, V. S., Lin, P. N., Mikhalenko, V. N., Campen, R. K., Bolzan, J. F., Cole-Dai, J., and Francou, B.: A 25,000-Year tropical climate history from Bolivian ice cores, Science, 282, 1858-1864, doi:10.1126/science.282.5395.1858, 1998.

Thompson, L. G., Yao, T., Mosley-Thompson, E., Davis, M., Henderson, K. A., and Lin, P. N.: A high-resolution millennial record of the South Asian Monsoon from Himalayan ice cores, Science, 289, 1916-1919, doi:10.1126/science.289.5486.1916, 2000.

Thompson, L. G., Mosley-Thompson, E., Davis, M. E., Henderson, K. A., Brecher, H. H., Zagorodnov, V. S., Mashiotta, T. A., Lin, P. N., Mikhalenko, V. N., Hardy, D. R., and Beer, J.: Kilimanjaro ice core records: Evidence of Holocene climate change in tropical Africa, Science, 298, 589-593, doi:10.1126/science.1073198, 2002.

Thompson, L. G., Mosley-Thompson, E., Brecher, H. H., Davis, M., Leon, B., Les, D., Lin, P. N., Mashiotta, T. A., and Mountain, K.: Abrupt tropical climate change: Past and present, P. Natl. Acad. Sci. USA, 103, 10536-10543, doi:10.1073/pnas.0603900103, 2006.

Uglietti, C., Zapf, A., Jenk, T. M., Szidat, S., Salazar, G., and Schwikowski, M.: Radiocarbon dating of glacier ice: overview, optimizations, validation and current potential, submitted to The Cryosphere, 2016.
United-Nations-Scientific-Committee-on-the-Effects-of-AtomicRadiation: Sources, effects and risks of ionizing radiation, exposures to the public from man-made sources of radiation, Annex C, UNSCEAR 2000 report to the general assembly, United Nations, New York, 287 pp., 2000.

Van de Velde, K., Barbante, C., Cozzi, G., Moret, I., Bellomi, T., Ferrari, C. P., and Boutron, C. F.: Changes in the occurrence of silver, gold, platinum, palladium and rhodium in Mont Blanc ice and snow since the 18th century, Atmos. Environ., 34, 31173127, 2000a.

Van de Velde, K., Boutron, C. F., Ferrari, C., Moreau, A. L., Delmas, R. F., Barbante, C., Bellomi, T., Capodaglio, G., and Cescon, P.: A two hundred years record of atmospheric cadmium, copper and zinc concentrations in high altitude snow and ice from the French-Italian Alps, Geophys. Res. Lett., 27, 249-252, doi:10.1029/1999GL010786, 2000b.

van der Veen, C. J., Mosley-Thompson, E., Jezek, K. C., Whillans, I. M., and Bolzan, J. F.: Accumulation rates in South and Central Greenland, Polar Geog., 25, 79-162, doi:10.1080/10889370109377709, 2001.

Vimeux, F., de Angelis, M., Ginot, P., Magand, O., Casassa, G., Pouyaud, B., Falourd, S., and Johnsen, S.: A promising location in Patagonia for paleoclimate and paleoenvironmental reconstructions revealed by a shallow firn core from Monte San Valentín (Northern Patagonia Icefield, Chile), J. Geophys. Res., 113, D16118, doi:10.1029/2007JD009502, 2008.

Vollweiler, N., Scholz, D., Mühlinghaus, C., Mangini, A., and Spötl, C.: A precisely dated climate record for the last $9 \mathrm{kyr}$ from three high alpine stalagmites, Spannagel Cave, Austria, Geophys. Res. Lett., 33, L20703, doi:10.1029/2006GL027662, 2006.

Wagenbach, D., Münnich, K. O., Schotterer, U., and Oeschger, H.: The anthropogenic impact on snow chemistry at Colle Gnifetti, Swiss Alps, Ann. Glaciol., 10, 183-187, 1988.

Wang, N., Wu, X., Kehrwald, N., Li, Z., Li, Q., Jiang, $\mathrm{X}$., and $\mathrm{Pu}, \mathrm{J}$. : Fukushima Nuclear Accident Recorded in Tibetan Plateau Snow Pits, PLoS One, 10, e0116580, doi:10.1371/journal.pone.0116580, 2015.

Zemp, M., Haeberli, W., Hoelzle, M., and Paul, F.: Alpine glaciers to disappear within decades?, Geophys. Res. Lett., 33, L13504, doi:10.1029/2006GL026319, 2006. 